\title{
Independent Technical Review of the Regulatory Path Forward for Remediation of Material Disposal Area T, Technical Area 21, at Los Alamos National Laboratory
}

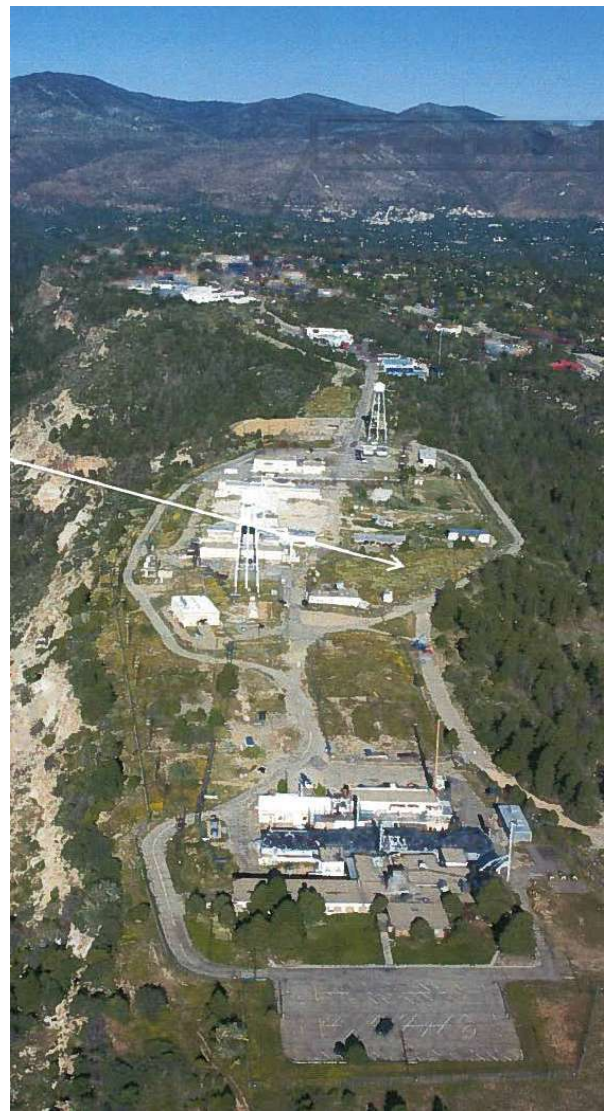

Prepared for: The U.S. Department of Energy Office of Environmental Management Office of Technology Innovation \& Development, Washington, DC

Prepared by: The DOE EM Center for Sustainable Groundwater and Soil Solutions, Savannah River National Laboratory, Aiken SC

June 2011 

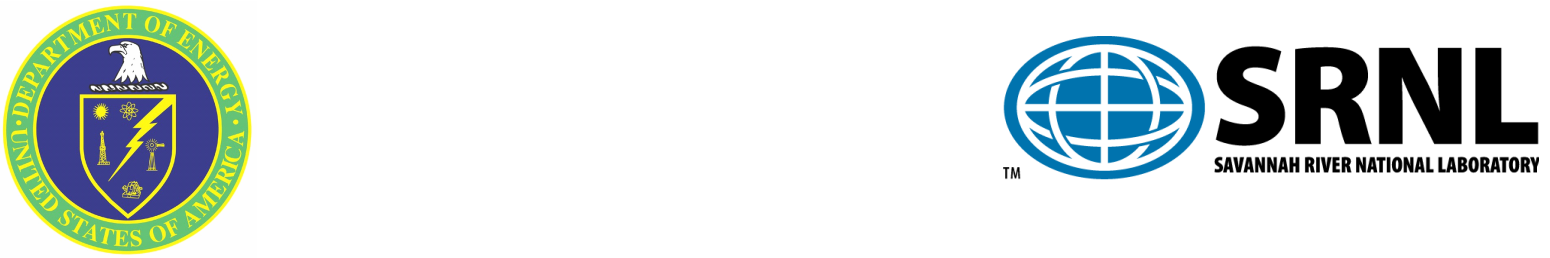

Cover Photo: Aerial View of Material Disposal Area T, Technical Area 21, at the Los Alamos National Laboratory

\section{DISCLAIMER}

This work was prepared under an agreement with and funded by the U.S. Government. While the authors have taken care in the preparation of this report, neither the U. S. Government or its employees, nor any of its contractors, subcontractors or their employees, makes any express or implied: 1. warranty or assumes any legal liability for the accuracy, completeness, or for the use or results of such use of any information, product, or process disclosed; or 2. representation that such use or results of such use would not infringe privately owned rights; or 3. endorsement or recommendation of any specifically identified commercial product, process, or service. Any views and opinions of authors expressed in this work do not necessarily state or reflect those of the United States Government, or its contractors, or subcontractors.

\section{Printed in the United States of America}

Prepared For

U.S. Department of Energy

Office of Technology Innovation \& Development 


\title{
Independent Technical Review of the Regulatory Path Forward for Remediation of Material Disposal Area T, Technical Area 21, at Los Alamos National Laboratory
}

\author{
Authors: \\ Mark Phifer (Technical Lead) \\ Roger Seitz \\ Richard Abitz \\ Carol Eddy-Dilek \\ Savannah River National Laboratory \\ Prepared for \\ Department of Energy (DOE) \\ Office of Technology Innovation \& Development \\ Washington, D.C.
}

June 2011

Technical content and coordination for this effort was provided by the Savannah River National Laboratory in conjunction with Contract No. DE-AC09-08SR22470 with the U.S. Department of Energy. 
\{blank page\} 


\section{Table of Contents}

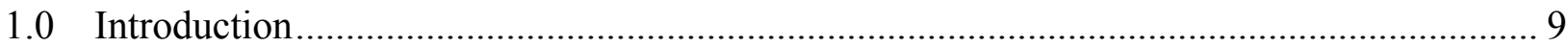

2.0 DOE TRU Waste Regulatory History..................................................................... 10

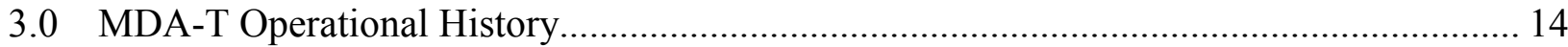

4.0 Current MDA-T Regulatory Status: Hazardous Waste ............................................... 17

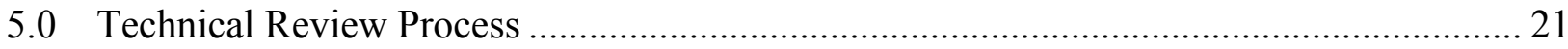

6.0 Summary of Potentially Applicable Directives, Orders, and Regulations........................ 22

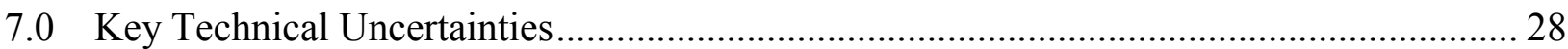

8.0 Review of Potential Pathways Developed by LANL .................................................. 31

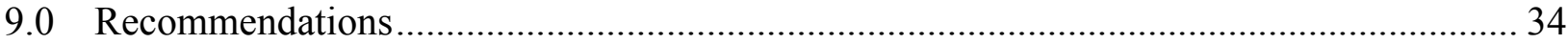

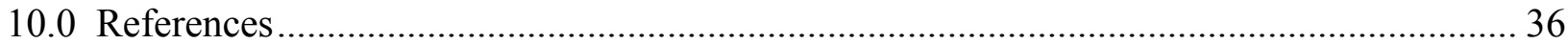

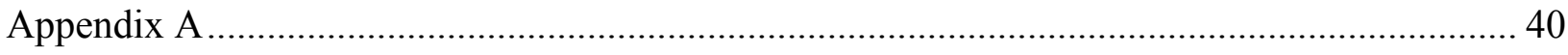

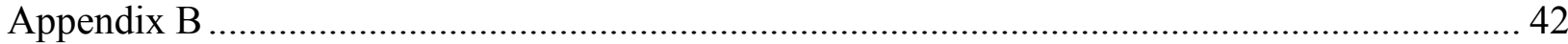

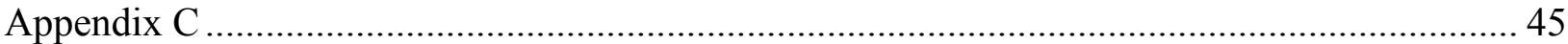




\section{Acronyms and Abbreviations}

$\begin{array}{ll}\text { AEC } & \text { Atomic Energy Commission } \\ \text { AOC } & \text { Area of Concern } \\ \text { ARAR } & \text { Applicable, or relevant and applicable requirements } \\ \text { CERCLA } & \text { Comprehensive Environmental Response, Compensation, and } \\ & \text { Compensation, and Liability Act } \\ \text { CFR } & \text { Code of Federal Regulations } \\ \text { Ci } & \text { Curie } \\ \text { CMPs } & \text { Corrugated Metal Pipes } \\ \text { COC } & \text { Contaminant of concern } \\ \text { cu } & \text { Cubic } \\ \text { cVOC } & \text { Chlorinated Volatile Organic Compound } \\ \text { DOE } & \text { U.S. Department of Energy } \\ \text { EM-32 } & \text { DOE Office of Groundwater and Soil Remediation } \\ \text { EPA } & \text { Environmental Protection Agency } \\ \text { FY } & \text { Fiscal Year } \\ \text { G } & \text { Gram } \\ \text { HWA } & \text { New Mexico Hazardous Waste Act } \\ \text { LANL } & \text { Los Alamos National Laboratory } \\ \text { MDA-T } & \text { Material Disposition Area T } \\ \text { mrem } & \text { Millirem } \\ \text { NMED } & \text { New Mexico Environment Department } \\ \text { NPL } & \text { National Priorities List } \\ \text { RCRA } & \text { Resource Conservation and Recovery Act } \\ \text { RWSA } & \text { Retrievable Waste Storage Area } \\ \text { SWMU } & \text { Solid Waste Management Unit } \\ \text { TCE } & \text { Trichloroethene } \\ \text { TRU } & \text { Transuranic } \\ \text { VOC } & \text { Volatile Organic Contaminant } \\ \text { WIPP } & \text { Waste Isolation Pilot Plant } \\ & \end{array}$




\section{Executive Summary}

The U. S. Department of Energy (DOE) is currently developing an appropriate and defensible basis to regulate in situ remediation of the radionuclide components of legacy waste at the Los Alamos National Laboratory (LANL) Material Disposal Area T (MDA$\mathrm{T})$. Because of the potential magnitude of the technical risk and cost of the remedial actions associated with MDA-T, DOE-EM was asked to provide an Independent Technical Review (ITR) team to review and evaluate the viability of regulatory pathways that have been developed by the LANL site team for the radiological components of legacy waste at MDA-T.

The evaluation by the Independent Technical Review included:

- An overview of DOE's transuranic (TRU) waste regulatory history, which provides perspective for this evaluation,

- An overview of the MDA-T operational history, which provides the technical basis with which to judge the appropriateness of potential regulatory bases,

- An overview of the current MDA-T hazardous waste regulatory status, with which any DOE radionuclide regulatory path must be integrated,

- An evaluation of potentially applicable directives, orders, and regulations that could form the DOE radionuclide regulatory basis,

- A listing of key technical uncertainties, which if addressed would help clarify the viability and relative merits of different regulatory options, and

- A review and evaluation of potential DOE regulatory pathways previously developed by LANL

This evaluation led to the identification of two applicable and potentially viable DOE regulatory pathways for the in situ remediation of the radionuclide components of legacy waste at MDA-T:

- DOE Order 458.1

- CERCLA non-time critical removal actions under DOE authority (40 CFR Part $300.415)$

During their analysis of the regulatory pathways, the team made two key assumptions that underpin the recommendations. These assumptions include the following:

- The legacy TRU waste in the MDA-T vertical Disposal Shafts was emplaced as a cementitious waste form, which was considered permanent disposal at the time of emplacement rather than temporary storage for future retrieval.

- The present in situ remediation path analysis for MDA-T deals with future in situ remedial actions and not future excavation and disposal actions.

The team recommends that one or both of these applicable and viable regulatory pathways (i.e. DOE Order 458.1 and CERCLA) should be considered for MDA-T, and the pathway selection process should include resolution of key technical uncertainties 
associated with the regulation and in situ remediation of MDA-T that were identified by the team. These uncertainties should be addressed to help clarify the viability and relative merits these two regulatory options (i.e. DOE Order 458.1 and CERCLA). In addition, as part of the decision making process, the team recommends that scoping calculations be performed to assess the impacts of leaving the legacy waste in place, and these informal evaluations should be compared with performance objectives in the relevant DOE orders.

A higher degree of credibility could be assigned to in situ remediation of MDA-T if an exception letter to IAD 0511-21 exists, because its existence would unequivocally defend the remedial action position and eliminate the discussion on whether the post-1970 TRU disposal actions (up through 1975) at MDA-T were formally sanctioned.

Although the primary focus of the team was to recommend regulatory pathways for in situ remedial options, the team also looked at the option to exhume, characterize, repackage, and dispose of the legacy waste at the Waste Isolation Pilot Plant (WIPP). Presently, there is insufficient information on the physical form of some waste components and the fission inventory to determine if the legacy waste in the MDA-T shafts will meet the WIPP Waste Acceptance Criteria (WAC). Prior to any administrative action that considers exhuming the legacy waste, it is recommended that LANL meet with WIPP waste representatives to discuss the physical, chemical and inventory properties of the waste to determine if the waste will meet the WIPP WAC. If the legacy waste is shown to not meet the WIPP WAC, then the in situ remedial option with the associated regulatory pathways discussed herein would become the sole viable option. If the waste is shown to meet the WIPP WAC, the selection of this path will require that risks be assessed for radiation exposure and safety incidents during excavation, handling, packaging, and transportation of the waste. At a minimum, it is recommended that a risk and cost analysis be performed to demonstrate whether retrieval of the waste and shipment to WIPP is more beneficial to DOE than in situ remediation of MDA-T. 


\subsection{Introduction}

The Los Alamos National Laboratory (LANL) requested assistance from the Department of Energy Office of Environmental Management (EM-32) and the Center for Sustainable Groundwater and Soil Solutions at the Savannah River National Laboratory to provide an independent technical panel to review the current regulatory path designed to address transuranic (TRU) legacy waste at the Material Disposal Area T (MDA-T), Technical Area 21, at LANL (Appendix A).

In 1970, the Atomic Energy Commission (AEC) promulgated Immediate Action Directive (IAD) 0511-21 that required that shallow land burial of TRU wastes be discontinued, and that such wastes be maintained in a "readily retrievable" configuration, pending the availability of a geologic repository (which we recognize today as the Waste Isolation Pilot Plant (WIPP) facility in southeastern New Mexico). This directive has been followed for the most part by all DOE sites, including LANL. However, LANL disposed of TRU waste in Disposal Shafts some 5 years after the AEC directive but prior to the promulgation of 40 CFR Part 191 in 1985, which governs the disposal of TRU waste.

The key issue for the technical review panel is to evaluate whether a radiological impact analysis needs to address 40 CFR Part 191 performance objectives, DOE Orders, or some other regulation to demonstrate protection of human health and the environment for the anticipated in situ remediation of TRU legacy waste at MDA-T. The request specifies that the team should determine which DOE Orders, combinations of Orders, or other regulations dictate the radiological path forward for the in situ remediation of MDA-T, where approximately 4000 curies of americium, plutonium, uranium, and mixed-fission products are present in a non-retrievable form. 


\subsection{DOE TRU Waste Regulatory History}

In order to provide context for the operational history of MDA-T (see Section 3.0) relative to evaluation of the appropriate regulatory path forward for the MDA-T TRU legacy waste, an overview of the evolution of regulations associated with DOE's TRU waste and the development of a TRU waste disposal option is provided below. A comparison of the MDA-T operational history with DOE's TRU waste regulatory history demonstrates that TRU waste disposal at MDA-T was phased out and retrievable TRU waste storage was phased in, during the time period that DOE and EPA were developing the definition of TRU waste, guidance for its management, and regulations for its disposal, and prior to the time that WIPP was available for the disposal of TRU waste.

The regulatory history for DOE's management of TRU waste has been an iterative and evolutionary process (see Table 1). Prior to 1970 transuranic (TRU) waste was not a separate category of radioactive waste but was included as low-level radioactive waste. On March 20, 1970 the Atomic Energy Commission (AEC) issued an Immediate Action Directive (IAD) that required "wastes with known or detectable contamination of transuranium nuclides" be retrievably stored after April 30, 1970. Those offices which could not comply could submit an exception letter stating the reason for noncompliance and a date when compliance could be achieved for approved by the AEC. However at the time a definition of TRU waste was not provided and no guidance was provided relative to what retrievable storage meant.

On September 19, 1973 the AEC Manual was revised with the addition of Chapter 0511, Radioactive Waste Management, which provided a definition of TRU waste and some guidance on its management. This AEC Manual chapter superseded AEC IAD 0511-21. Transuranic solid waste was defined as waste "contaminated with certain alpha-emitting radionuclides of long half-life and high specific radiotoxicity to greater than $10 \mathrm{nCi} / \mathrm{g}$." Such waste was to be stored "such that the packages can be readily retrieved in an intact, contamination-free condition for 20 years." Additionally each site was to develop a radioactive waste management plan discussing current and planned management of radioactive wastes, including associated budgets.

A Los Alamos Scientific Laboratory (LASL) report (LA-6545) entitled, "Guidelines for the Interim Storage of AEC-Generated Solid Transuranic Wastes", was issued in June 1974 by the LASL Waste Management Section for use within the AEC complex. The guidelines were developed to provide a basis for the adequacy of packaging, handling, and storage of retrievable TRU solid wastes, as defined by the AEC Manual Chapter 0511.

In 1982 the definition of TRU waste was substantially changed within DOE Order 5820.1, Management of Transuranic Contaminated Material, issued on September 30, 1982. TRU waste was re-defined as waste "contaminated with alpha-emitting radionuc1ides of atomic number greater than 92 and half-lives greater than 20 years in concentrations greater than $100 \mathrm{nCi} / \mathrm{g}$." This is the current definition of TRU waste. 
This order also provided guidance for the generation, treatment, packaging, storage, transportation, and disposal of TRU waste in anticipation of the Waste Isolation Pilot Plant (WIPP). Additionally this order required that TRU waste disposed prior to the order's implementation (i.e. 9/30/82) be monitored and remedial actions performed as appropriate.

Subsequent revisions of DOE orders associated with TRU waste (i.e. DOE Orders $5820.2,5820.2 \mathrm{~A}$, and 435.1) were made as progress continued toward the regulation and operation of WIPP for the disposal of DOE's TRU waste. DOE Order 5820.2, Radioactive Waste Management, was issued on February 6, 1984, superseding DOE Order 5820.1. The previous DOE Order 5820.1 definition for TRU waste was retained. The order primarily addressed certification and storage of TRU waste in preparation for disposal at WIPP. Additionally this order required that TRU waste that had been buried in shallow land burial sites or emplaced on soil columns prior to issuance of this order (i.e. $2 / 6 / 84$ ) be periodically monitored to evaluate its safety and to determine if corrective measures were necessary. Finally this order required development of an initial implementation plan and annual waste management plans.

The Environmental Protection Agency (EPA) issued 40 CFR Part 191, Environmental Radiation Protection Standards for Management and Disposal of Spent Nuclear Fuel, High-Level and Transuranic Radioactive Wastes, effective November 18, 1985. This regulation provides requirements for the storage and disposal of TRU waste after its effective date. It does not apply to wastes disposed of before November 18, 1985. The regulation defines TRU waste as waste containing more than $100 \mathrm{nCi} / \mathrm{g}$ alpha-emitting transuranic isotopes, with half-lives greater than twenty years, which is the same as the definition within DOE Orders 5820.1 and 5820.2. It specifies containment, individual protection, and groundwater protection standards, associated with TRU waste disposal and specifically addresses WIPP. 40 CFR Part 191 is a currently active regulation, and it is discussed in more detail in Section 6.0 and Appendix C.

DOE Order 5820.2A, Radioactive Waste Management, was issued on September 26, 1988, superseding DOE Order 5820.2. The previous DOE Orders 5820.1 and 5820.2 and 40 CFR Part 191 definition for TRU waste was retained. The order primarily addressed management of DOE transuranic waste including generation, treatment, certification, packaging, storage, shipping to WIPP, and closure of WIPP. It specifically addressed 40 CFR Part 191. Additionally the order addressed the management of buried transuranic waste as defined in DOE-JIO-025 (9/87), "Comprehensive Implementation Plan for the DOE Defense Buried Transuranic-Contaminated Waste Program," which describes long term management alternatives for all DOE sites with buried transuranic waste. The long term management of buried transuranic contaminated waste at inactive DOE waste sites, including LANL, was specifically addressed by the order and implementation plan. The following three site-closure strategies, which could be performed individually or in combination, were listed:

- Leave waste in place with enhanced monitoring. 
- Leave waste in place, use enhanced confinement or in situ immobilization techniques, and provide enhanced monitoring.

- Retrieve, process, and dispose of the transuranic waste at Waste Isolation Pilot Plant.

DOE Order 435.1, Radioactive Waste Management, was issued on July 9, 1999, superseding DOE Order 5820.2A. The previous DOE Orders 5820.1, 5820.2, and 5820.2A and 40 CFR Part 191 definition for TRU waste was retained. DOE Order 435.1 is the currently active radioactive waste management order, and it is discussed in more detail in Section 6.0 and Appendix C.

In conjunction with development of the definition of TRU waste and its regulatory basis, AEC/DOE began development of a disposal pathway for TRU waste. In 1974 AEC chose a salt bed east of Carlsbad, NM to explore as a potential site for an underground radioactive waste repository. Congress authorized the site as a research and development facility in 1979 to demonstrate the safe disposal of non-Nuclear Regulatory Commission (NRC) radioactive waste, and the first exploratory shaft was drilled in 1981. In 1985 the Environmental Protection Agency (EPA) issued the 40 CFR Part 191 regulations (see above), which specifically addressed TRU waste disposal at WIPP. The WIPP Land Withdrawal Act of 1992 transferred jurisdiction of the land to DOE from the Department of the Interior (DOI), prohibited the disposal of high-level waste and spent nuclear fuel at the site, and gave EPA the responsibility for determining compliance with federal radioactive waste disposal regulations. EPA certified that WIPP met all applicable federal radioactive waste disposal regulations in 1998, and the first shipment of TRU waste to WIPP came from LANL in March 1999. 
Table 1. DOE TRU Waste Regulatory History

\begin{tabular}{|c|c|c|}
\hline Date & Document & TRU Waste Definition and Requirements \\
\hline $3 / 20 / 70$ & $\begin{array}{l}\text { AEC IAD 0511- } \\
21\end{array}$ & $\begin{array}{l}\text { - Waste contaminated with transuranium nuclides (no } \\
\text { specified lower limit) } \\
\text { - } \quad \text { Retrievably stored or written exception request }\end{array}$ \\
\hline $9 / 19 / 73$ & $\begin{array}{l}\text { AEC Manual } \\
\text { Chapter } 0511\end{array}$ & $\begin{array}{l}\text { - Waste contaminated with greater than } 10 \mathrm{nCi} / \mathrm{g} \text { of } \\
\text { transuranics with a long half-life } \\
\text { - Retrievably stored }\end{array}$ \\
\hline $6 / 74$ & $\begin{array}{l}\text { LA-6545, TRU } \\
\text { Waste Guidelines }\end{array}$ & $\begin{array}{l}\text { - Waste contaminated with greater than } 10 \mathrm{nCi} / \mathrm{g} \text { of } \\
\text { transuranics with a long half-life } \\
\text { - Guidelines for the packaging, handling, and storage of } \\
\text { retrievable TRU waste }\end{array}$ \\
\hline $9 / 30 / 82$ & $\begin{array}{l}\text { DOE Order } \\
5820.1\end{array}$ & $\begin{array}{l}\text { Waste contaminated with greater than } 100 \mathrm{nCi} / \mathrm{g} \\
\text { alpha-emitting transuranics with half-lives greater } \\
\text { than } 20 \text { years } \\
\text { Guidelines for the generation, treatment, packaging, } \\
\text { storage, transportation, and disposal of TRU waste in } \\
\text { anticipation of disposal at WIPP } \\
\text { TRU waste disposed prior to order implementation to } \\
\text { be monitored and remedial actions performed where } \\
\text { appropriate }\end{array}$ \\
\hline $2 / 6 / 84$ & $\begin{array}{l}\text { DOE Order } \\
5820.2\end{array}$ & $\begin{array}{l}\text { - TRU waste definition same as DOE Order } 5820.1 \\
\text { - Guidelines for certification and stored of TRU waste } \\
\text { in preparation for disposal at WIPP } \\
\text { - TRU waste disposed prior to issuance of this order to } \\
\text { be monitored and the need for corrective measures to } \\
\text { be determined }\end{array}$ \\
\hline $9 / 19 / 85$ & 40 CFR Part 191 & 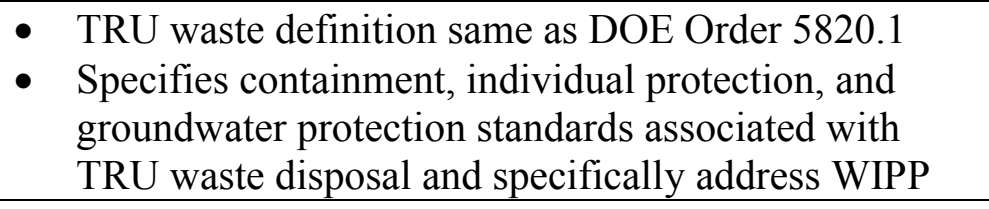 \\
\hline $9 / 26 / 88$ & $\begin{array}{l}\text { DOE Order } \\
5820.2 \mathrm{~A}\end{array}$ & $\begin{array}{l}\text { - TRU waste definition same as DOE Order } 5820.1 \\
\text { - Specifies requirements for the generation, treatment, } \\
\text { certification, packaging, storage, and shipping TRU } \\
\text { waste to WIPP, and closure of WIPP } \\
\text { Provided closure strategies for buried transuranic } \\
\text { contaminated waste at inactive DOE waste sites, } \\
\text { including LANL }\end{array}$ \\
\hline 7/9/99 & DOE Order 435.1 & $\begin{array}{l}\text { - TRU waste definition same as DOE Order } 5820.1 \\
\text { - Specifies requirements for the generation, treatment, } \\
\text { certification, packaging, storage, and shipping TRU } \\
\text { waste, and disposal of TRU waste in accordance with } \\
\text { 40 CFR Part } 191\end{array}$ \\
\hline
\end{tabular}




\subsection{MDA-T Operational History}

MDA-T is a fenced, 2.2 acre open field located within Technical Area 21 at LANL that contains 4 absorption beds, 64 disposal shafts, and the historical Retrievable Waste Storage Area (RWSA) (See Figure 1). The operational history of MDA-T is complex, with continuous waste disposal and/or storage activities from 1945 until the site was backfilled, graded, and closed to further disposal/storage in 1986. The waste disposed at MDA-T includes both radiological and hazardous components including volatile organic compounds (carbon tetrachloride, chloroform, methylene chloride, perchloroethylene, and trichloroethylene). In 1986, the area was backfilled, and the site was graded to drain to the north.

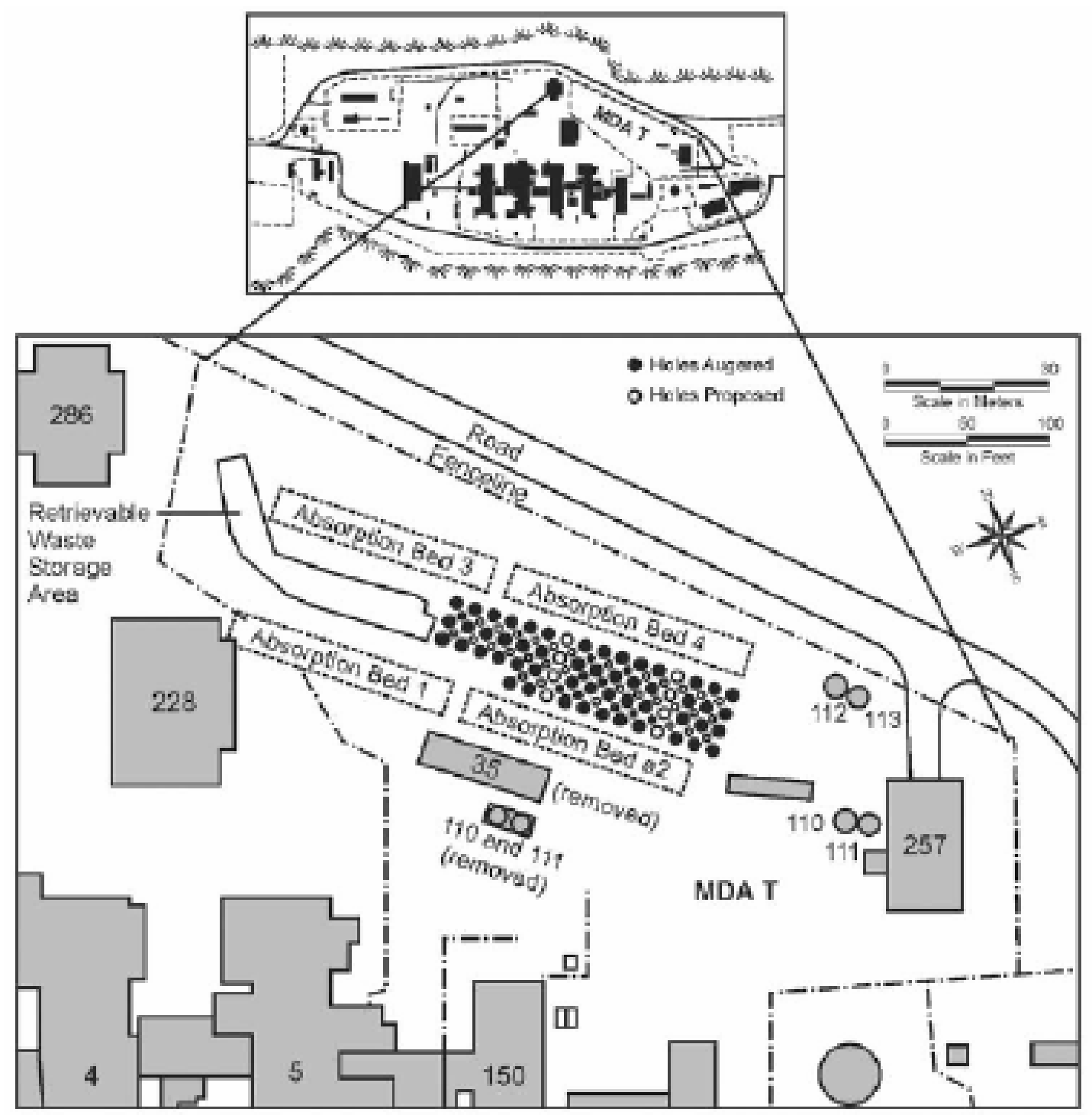

Figure 1. MDA-T Absorption Beds, Disposal Shafts, and RWSA 
Construction of four absorption beds was completed in 1945 (Figure 1). Each rock-filled absorption bed was constructed in Bandelier Tuff, and measured approximately 120 feet long, 20 feet wide, and 4 feet deep. Approximately 18.3 million gallons of wastewater were discharged to the absorption beds between 1945 and 1967. The absorption beds received untreated liquid waste (14 million gallons) between 1945 and 1952, and treated liquid waste (4.3 million gallons) between 1952 and 1967. In 1967, a new wastewater treatment plant (Building TA-21-257) became operational, and all discharge to the absorption beds was discontinued. In 1973, it was estimated that the absorption beds contained $4 \mathrm{Ci} \mathrm{H}-3$ and $10 \mathrm{Ci} \mathrm{Pu}-239$.

Between 1968 and 1974, approximately sixty-four shafts, 6-foot diameter and 8-foot diameter, some asphalt-lined, were installed 15 feet to 69 feet deep, between absorption beds 2 and 4 (Figure 1). Between 1968 and 1983, the disposal shafts received predominately treated liquid wastes mixed with cement. Five of the shafts have bathyspheres that contain plutonium-239/240 and other mixed fission products (predominately strontium and cesium). In addition, some shafts received unspecified volumes of wash water. Some of the waste disposed through 1975 is classified as transuranic (TRU) waste $(100 \mathrm{nCi} / \mathrm{g})$. Once the shafts were filled with the waste-cement mixture, they were capped. In 2004, it was estimated that the disposal shafts contained

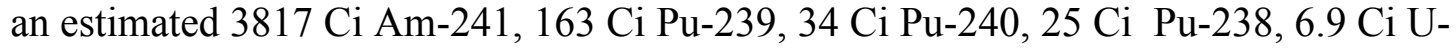
233, and 0.0015 Ci U-235.

The RWSA was excavated in 1974 between absorption beds 1 and 3 (Figure 1). The excavated pit measured 1200 feet long by 24 feet wide by 19 feet deep. Treated wastes from the new wastewater treatment plant (Building TA-21-257) containing Pu-239/240 and Am-241 were mixed with cement and pumped into the corrugated metal pipes (CMPs). The RWSA provided temporary storage for a total of 227 CMPs. In 1984, 69 pipes were transferred to Area G Pit 26, and in 1986, 158 CMPs were transferred to the Area G PIT 29.

Figure 2 places the timeline for radioactive waste disposal and storage at MDA-T in perspective relative to the regulatory history for DOE's management of TRU waste (see Section 2.0). As seen TRU waste disposal within the Disposal Shafts was phased out and retrievable TRU waste storage within the RWSA was phased in, during the time period that DOE and EPA were developing the definition of TRU waste, guidance for its management, and regulations for its disposal.

(DOE 2008; LANL 2006; LANL 2009; LANL 2011; Rogers 1977; Travers, Alexandrova, and Resnikoff 2009) 


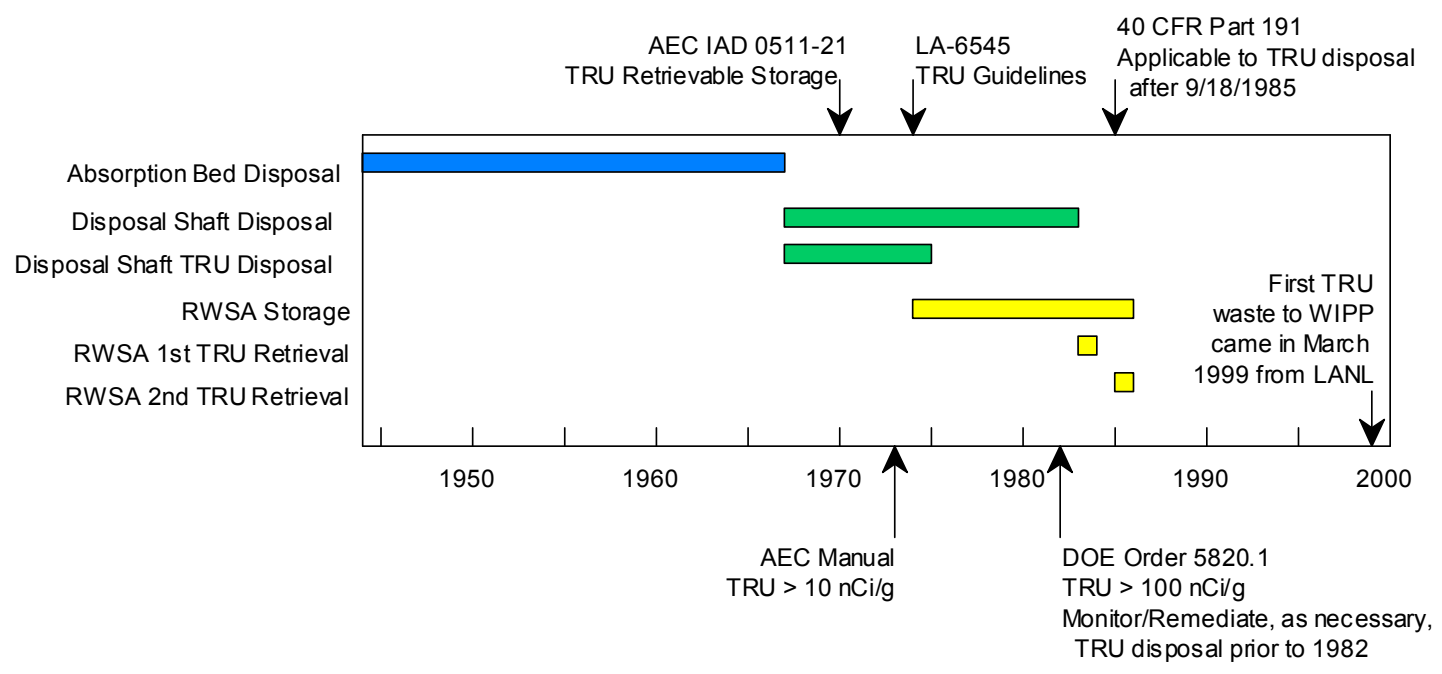

Figure 2. MDA-T Timeline versus DOE TRU Waste Regulatory History 


\subsection{Current MDA-T Regulatory Status: Hazardous Waste}

Currently the hazardous waste components of the legacy waste at the MDA-T are regulated by the New Mexico Environment Department (NMED) through the New Mexico Hazardous Waste Act (HWA), under the Resource Conservation and Recovery Act (RCRA) authorization from the Environmental Protection Agency (EPA) to the State of New Mexico. The radionuclide components of the legacy waste at the MDA-T are subject to Department of Energy (DOE) authority under a yet to be determined regulatory framework. LANL is not on the Comprehensive Environmental Response, Compensation, and Liability Act (CERCLA) National Priorities List.

The state of New Mexico received RCRA authorization from EPA to implement its Hazardous Waste Act in lieu of RCRA on January 25, 1985. Further, the state received EPA authorization to implement its HWA corrective action program on January 2, 1996 (NMED 2005; NMED 2008).

A NMED/LANL Consent Order, pursuant to the HWA (NMSA 1978, 74-4-10) and to the New Mexico Solid Waste Act (SWA) (NMSA 197874-9-36(D)), was entered into by the NMED, DOE, and the University of California (UC) and became effective March 1, 2005. On June 18, 2008, the Order was modified to add Section IV.A.g, which covers the notification requirements for groundwater monitoring results and to make revisions to the deliverables (NMED 2005; NMED 2008).

The Consent Order does not apply to radionuclides or the radioactive portion of mixed waste. It does apply to the hazardous waste component of mixed waste. Therefore, any radionuclides found in any media at LANL are not subject to enforcement action under the Consent Order. However LANL may voluntarily include in any plan, report, or other document submitted pursuant to this Consent Order, information concerning radionuclides or the radioactive portion of mixed waste. The voluntary inclusion of such radionuclide information by LANL falls wholly outside the requirement of the Consent Order. (NMED 2005; NMED 2008)

The NMED/LANL Consent Order (NMED 2005; NMED 2008) requires LANL to produce the following deliverables in association with MDA-T (Consolidated Unit SWMU 21-016(a)-99):

- Investigation Work Plans

- Investigation Reports

- Corrective Measures Evaluation

- Corrective Measures Implementation Plan

- Remedy Completion Report 
The following are specific requirements associated with each of these MDA-T deliverables (NMED 2005; NMED 2008):

- MDA-T Investigation Work Plan: The work plan shall address investigations of the disposal units; migration pathways and the connections to potential receptors including groundwater; and the nature and extent of contamination in soil, rock, sediments, groundwater (where present), and subsurface vapor (if detected) at MDA-T. Investigations at MDA-T are required to include the following:

- MDA T Survey of Disposal Units: The dimensions and total depth of each disposal trench, absorption bed, shaft, pit, and other unit at MDA-T into which waste was disposed, and the base profile, topography, low elevation point, and down-slope end of the base of each disposal trench, shaft, pit, and absorption bed at MDA-T shall be determined.

- MDA-T Drilling Explorations: Subsurface explorations shall be conducted to obtain sufficient data to characterize the extent of contamination, and to characterize fracture density, fracture orientation, and fracture fill material or the absence of fracture fill material in rock surrounding and below MDA-T.

- MDA-T Soil and Rock Sampling: During subsurface exploration activities that include soil and rock sampling, screening, and analysis shall be conducted. For each boring, samples shall be submitted for laboratory analysis including the sample exhibiting the highest field screening detection; the sample obtained from the maximum depth that displays field screening evidence of contamination; the sample located immediately below the base of any pit, tank, or other structure; and the sample from the total boring depth. The laboratory shall analyze the selected samples for VOCs, SVOCs, explosive compounds, pH, PCBs, dioxins, furans, nitrates, perchlorate, TAL metals, and cyanide.

- MDA-T Sediment Sampling: Contaminant transport from MDA-T to canyon alluvial sediments shall be investigated.

- MDA-T Vapor Monitoring and Sampling: Subsurface vapor samples shall be collected from discrete zones in each subsurface vapor monitoring well or boring, at depths approved by the NMED, for field and laboratory analyses.

- MDA-T Intermediate Groundwater Well Installation: If perched groundwater is encountered or if geophysical or other evidence suggests the presence of perched groundwater during the required subsurface investigations for MDA-T, NMED may require the installation of perched groundwater monitoring well(s).

- MDA-T Regional Groundwater Well Installation: If NMED determines that additional regional groundwater aquifer well(s) are needed then they shall be installed.

- MDA-T Groundwater Monitoring: Specified alluvial, perched, and regional groundwater wells shall be monitored, sampled, and analyzed for general chemistry parameters, perchlorate, TAL metals, cyanide, VOCs, SVOCs, explosive compounds, and for other analytes specified by NMED. 
- MDA-T Investigation Report: An investigation report that presents the results of the field activities, summarizes the data collected, and presents the recommendations and conclusions for MDA-T shall be submitted to NMED for review and written approval.

- $\quad$ Corrective Measures Evaluation Report and Risk Analysis: Whenever NMED determines that there has been a release of contaminants into the environment, at a Solid Waste Management Unit (SWMU) or Area of Concern (AOC), that requires corrective action to protect human health or the environment, based on the Investigation Report and other relevant information, a Corrective Measures Evaluation Report will be required, consistent with the agreed upon schedule. The Corrective Measures Evaluation Report is required to evaluate potential remedial alternatives and shall recommend a preferred remedy that will be protective of human health and the environment and attain the appropriate cleanup goals. The Corrective Measures Evaluation Report serves as a Corrective Measures Study for the purposes of RCRA compliance. Additionally, whenever corrective action is required, an accompanying risk analysis report is also required. The risk analysis shall be used to establish cleanup goals. Both the Corrective Measures Evaluation Report and the accompanying risk evaluation shall be reviewed and approved by NMED.

- Remedy Selection: Upon approval of the Corrective Measures Evaluation Report, NMED will select a remedy or remedies for the SWMU or AOC. NMED may choose a different remedy from that recommended within the report. NMED will issue a Statement of Basis for selection of the remedy, and will receive public comment on the remedy.

- $\quad$ Corrective Measures Implementation Plan: After NMED's selection of a final remedy, consistent with the agreed upon schedule, a Corrective Measures Implementation Plan shall be prepared. The plan will outline the design, construction, operation, maintenance, and performance monitoring for the selected remedy, and a schedule for its implementation. The Corrective Measures Implementation Plan shall be reviewed and approved by NMED.

- $\quad$ Remedy Completion Report: After remedy completion, consistent with the agreed upon schedule, a Remedy Completion Report shall be prepared. The report shall include a summary of the work completed; registered professional engineer certification; registered professional engineer signed and stamped as-built drawings and specifications; remedy implementation monitoring results (including sampling and analysis); copies of all waste disposal records; and DOE and co-operator certification.

Table 2 provides the MDA-T specific deliverable dates contained within the NMED/LANL Consent Order (NMED 2008). In 2010 NMED (Bearzi 2010) listed the MDA-T Remedy Completion Report on the list of documents subject to penalties under the Consent Order and suggested that LANL submit a request for extension for the Remedy Completion Report in accordance with Section III.J.2 of the Consent Order. LANL subsequently submitted a request to NMED for the revised deliverable dates as outlined in Table 3 (Graham and Rael 2010). As yet NMED has not officially responded to the extension request. 
Table 2. MDA-T Consent Order Deliverables (NMED 2008)

\begin{tabular}{|l|l|l|}
\hline \multicolumn{1}{|c|}{ Deliverable } & \multicolumn{1}{c|}{ Due Date } & Notice Date \\
\hline $\begin{array}{l}\text { Long-term Subsurface Vapor Monitoring } \\
\text { and Sampling Work Plan }\end{array}$ & $\begin{array}{l}\text { Prior to program } \\
\text { implementation }\end{array}$ & \\
\hline Investigation Work Plan & $2 / 29 / 04 \mathrm{~A}$ & $5 / 19 / 05 \mathrm{~A}$ \\
\hline Investigation Report & $9 / 18 / 06 \mathrm{~A}$ & $1 / 16 / 07$ \\
\hline Phase II Investigation Work Plan & $2 / 15 / 07 \mathrm{~A}$ & $4 / 30 / 07$ \\
\hline Phase II Investigation Report & $11 / 15 / 07$ & $3 / 15 / 08$ \\
\hline Remedy Completion Report & $12 / 19 / 10$ & $4 / 18 / 11$ \\
\hline
\end{tabular}

$\mathrm{A}=$ actual

Table 3. Revised MDA-T Deliverables (Graham and Rael 2010)

\begin{tabular}{|l|l|}
\hline \multicolumn{1}{|c|}{ Deliverable } & \multicolumn{1}{|c|}{ Due Date } \\
\hline Corrective Measures Evaluation Report (including risk drivers) & $12 / 11 / 12$ \\
\hline Corrective Measures Implementation Plan & $12 / 15 / 13$ \\
\hline Remedy Completion Report & $2 / 11 / 15$ \\
\hline
\end{tabular}




\subsection{Technical Review Process}

The technical assistance panel used a structured stepwise process to evaluate the applicability of various DOE Orders and other regulations to the in situ remediation of the radionuclide portion of the legacy waste present at MDA-T. Ex situ remediation (i.e. excavation and WIPP disposal) already has a well defined DOE regulatory pathway and does not require further evaluation.

First a list of questions was developed to help frame the discussions for a path forward for MDA-T (Appendix B). Based on information that was provided to the team for review and discussed during a series of conference calls, it appears that many of the questions and uncertainties that were identified have already been considered by LANL personnel in the course of previous efforts to identify a path forward. Second, a consensus was developed on key assumptions and the relevant background scientific and technical information. The team then compiled a list of potentially applicable directives, orders, and regulations for the radionuclide portion of the legacy waste at MDA-T. A consensus was developed within the team on important points, and then the team determined whether the individual regulations were applicable to MDA-T. As part of this process, key technical uncertainties were identified that need to be addressed to optimize the selection and implementation of the regulatory pathway. This evaluation proved to be a powerful tool for the team to evaluate the regulatory pathways that had previously been developed for MDA-T by LANL personnel and to make recommendations for a technical and regulatory strategy to address the radionuclide portion of the legacy waste at MDAT.

Key assumptions for the recommendations in this review include:

1) The TRU waste in the MDA-T vertical shafts was emplaced as a cementitious waste form and was considered permanent disposal at the time of emplacement rather than temporary storage for future retrieval. This disposal was conducted prior to promulgation of 40 CFR Part 191. Within the preamble to 40 CFR Part 191 (50 FR 38066), EPA stated that the disposal standards do not apply to transuranic waste that had already been disposed prior to promulgation of the standards, because the selection of disposal system site, design, and operational techniques are no longer available options. This is important because the regulatory standards applied to MDA-T should be those applicable to a remedial or corrective action rather than a current disposal activity.

2) Other RCRA corrective actions for historic disposal activities at LANL have been conducted using remediation or corrective action criteria rather than disposal criteria. It is desirable to use assumptions consistent with other activities at the LANL site.

3) Performance objectives for remedial actions in DOE Order 458.1 are considered protective of human health and the environment. After all the actions are taken, the final objective is to ensure that the selected options are protective of human health and the environment. 


\subsection{Summary of Potentially Applicable Directives, Orders, and Regulations}

As outlined in Section 4.0, the New Mexico HWA and the subsequent NMED/LANL Consent Order are applicable to the regulation of the remediation of the hazardous waste components of the legacy waste at the MDA-T. The NMED/LANL Consent Order has placed MDA-T on the path to a corrective action (i.e. remediation) with a proposed Remedy Completion Report due date of February 11, 2015 (see Table 3). Also, as specified within the Consent Order, remediation of the radionuclide components of the legacy waste at the MDA-T are subject to DOE authority under a yet to be determined regulatory framework.

An evaluation of the following directives, orders, and regulations was conducted in relation to their potential applicability to DOE's execution of the potential in situ remediation of the radionuclide components of the legacy waste at the MDA-T. Ex situ remediation (i.e. excavation and WIPP disposal) already has a well defined DOE regulatory pathway and does not require further evaluation.

- AEC IAD 0511-21

- DOE Order 458.1, Radiation Protection of the Public and the Environment

- DOE Order 435.1, Radioactive Waste Management

- 40 CFR Part 191, Environmental Radiation Protection Standards for Management and Disposal of Spent Nuclear Fuel, High-Level and Transuranic Radioactive Wastes (EPA)

- 40 CFR Part 300, National Oil And Hazardous Substances Pollution Contingency Plan (CERCLA)

- 10 CFR Part 61, Licensing Requirements For Land Disposal Of Radioactive Waste (NRC)

Table 4 provides a brief description of each directive/order/regulation, a summary of its applicability to MDA-T, and relevant comments and performance requirements.

Appendix $\mathrm{C}$ provides an overview of each directive/order/regulation including its scope, general applicability, and details for relevant performance requirements.

AEC IAD 0511-21 required that after April 30, 1970 TRU waste be retrievably stored, unless an exception letter from the generator was approved by AEC. Such an exception letter is not known to exist for MDA-T, and TRU waste was disposed within the MDA-T disposal shafts through 1975 (see Section 3.0). This disconnect has resulted in uncertainty regarding the regulatory framework for radionuclide components of the legacy waste at the MDA-T, and it is the basis for this evaluation to help determine the appropriate regulatory framework for DOE to utilize.

DOE Order 458.1, Radiation Protection of the Public and the Environment, is applicable to LANL. The DOE Order 458.1 Public Dose Limits (Table 4) are applicable at the 
LANL boundary from all sources and exposure pathways that could significantly contribute to dose, including MDA-T. The air and groundwater performance requirements are applicable at the MDA-T boundary. Finally the order requires that TRU disposal comply with 40 CFR Part 191.

DOE Order 435.1, Radioactive Waste Management, Chapter III, Transuranic Waste Requirements (effective on July 9, 1999) is applicable to the storage, treatment, and disposal of TRU waste. It clearly states that TRU waste disposed prior to implementation of AEC Immediate Action Directive 0511-21 (i.e. pre-1970 TRU waste) is not regulated by DOE Order 435.1. It also notes that the order is not applicable to the remediation of inactive waste sites containing buried TRU waste, unless such remediation results in the storage, treatment, and disposal of TRU waste (i.e. excavation and off-site disposal). In general this means that DOE Order 435.1 is not applicable to possible in situ remediation of MDA-T. Additionally as discussed in Section 2.0, DOE Orders 5820.1, 5820.2, and 5820.2A, were predecessors to DOE Order 435.1. These predecessors to DOE Order 435.1 specifically outlined actions to be taken in association with TRU waste, which had been disposed prior to the implementation of these prior orders (i.e. $9 / 30 / 82$ for DOE Order 5820.1). The actions outlined included monitoring and remedial actions, as necessary. The remedial actions could include in-place remediation or excavation and disposal at WIPP. These previous radioactive waste management orders could be pertinent to the remediation of MDA-T along with the DOE publication referenced by DOE Order 5820.2A (DOE-JIO-025 of 9-87, "Comprehensive Implementation Plan for the DOE Defense Buried Transuranic-Contaminated Waste Program"). More detailed information on DOE Order 5820.2A is provided in Appendix C. DOE Order 435.1 provides the following options for disposing of and regulating post-1970 TRU waste:

- Degree of Isolation: The Secretary of Energy and EPA Administrator may jointly determine that a waste does not require the degree of isolation required by 40 CFR Part 191.

- 10 CFR Part 61: On a case-by-case NRC may approve the disposal of a TRU waste within a NRC licensed low-level waste disposal facility under 10 CFR Part 61.

- Mixed TRU waste: Mixed TRU waste shall be managed in accordance with RCRA and DOE Order 435.1 requirements.

- TSCA-Regulated waste: TRU waste containing TSCA compounds shall be managed in accordance with TSCA and DOE Order 435.1.

- 40 CFR Part 191: TRU waste shall be disposed in accordance with 40 CFR Part 191 requirements.

DOE Order 435.1 also results in some of the ambiguity regarding the appropriate regulatory framework for radionuclide components of the legacy waste at the MDA-T. While the order clearly does not apply to pre-1970 TRU waste disposals, it requires compliance with 40 CFR Part 191 (see discussion below), which clearly states that it is not applicable to TRU waste disposals prior to 1985 . However DOE Order 435.1 does not within itself clearly state its applicability relative to TRU wastes disposals between 1970 and 1985. However as outlined above, the orders that preceded DOE Order 435.1 
did clearly state that they did not apply to TRU waste disposals prior to their implementation (i.e. 9/30/82 for DOE Order 5820.1). This lends additional credence to the non-applicable of DOE Order 435.1 to the in situ remediation of MDA-T.

40 CFR Part 191, Environmental Radiation Protection Standards for Management and Disposal of Spent Nuclear Fuel, High-Level and Transuranic Radioactive Wastes, is applicable to the storage and disposal of TRU waste. 40 CFR Part 191 Subpart B, Environmental Standards for Disposal, Section 191.11 (b) (2) states that this subpart does not apply to wastes disposed of before November 18, 1985. Within the preamble to 40 CFR Part 191 (50 FR 38066), EPA stated that the disposal standards do not apply to transuranic waste that had already been disposed prior to promulgation of the standards, because the selection of disposal system site, design, and operational techniques are no longer available options. Additionally 40 CFR Part 191 is not applicable to the remediation of inactive waste sites containing buried TRU waste, unless that remediation involves the excavation and off-site disposal of the TRU waste. Therefore 40 CFR Part 191 is not applicable to MDA-T, despite its citation by DOE Order 458.1 and DOE Order 435.1 as discussed above. However if it were to be determined that the radionuclide components of the legacy waste at MDA-T should be regulated under 40 CFR Part 191 for in situ remediation, then DOE would be the sole regulatory authority.

LANL is not listed on the National Priorities List (NPL); therefore MDA-T is not currently subject to CERCLA. CERCLA provides two types of hazardous action responses: removal actions and remedial actions. Removal actions are shorter termed actions responding to a threat that can be the final action or followed by or be a part of a remedial action. Remedial actions are longer termed actions that are undertaken following the full CERCLA process: remedial investigation / feasibility study, proposed plan, record of decision, and remedial design / remedial action. Under CERCLA Section 104, 42 U.S.C. $\S 9604$, DOE can conduct CERCLA non-time critical removal actions under their own authority with no explicit EPA role even at non-NPL sites such as MDAT. Such removal actions can include leaving the waste in place and capping to reduce migration, and it can be considered the final action. Prior to implementing a removal action an Engineering Evaluation / Cost Analysis (EE/CA) must be developed and the public must be involved. The primary purpose of the EE/CA is to provide a framework for evaluating and selecting alternative technologies. Additionally based upon a joint DOE/EPA memorandum (DOE/EPA 1998), it is recommended that DOE field offices work with their EPA regional counterparts to identify non-time critical removal actions estimated to exceed $\$ 75$ million at sites where the primary contaminants are radioactive, as possible candidates for review by EPA's National Remedy Review Board (NRRB). Use of CERCLA remedial action authority at a non-NPL RCRA regulated site, such as LANL, would likely require integration of the full CERCLA process for radionuclides with the existing RCRA process for hazardous waste components. In the case of LANL this would likely require an agreement between DOE and NMED regarding such integration and would possibly require a modification of the NMED/LANL Consent Order. (EPA 1993, EPA/DOE/DOD 1994, and DOE/EPA 1995) 
MDA-T is not a NRC licensed site, therefore 10 CFR Part 61, Licensing Requirements for Land Disposal of Radioactive Waste, is not applicable to MDA-T. The only way that 10 CFR Part 61 could potentially be applicable to MDA-T is if the MDA-T TRU legacy waste were excavated and disposed within an NRC licensed low-level waste disposal facility. Such TRU waste disposal within an NRC licensed LLW facility would require approved by NRC on a case-by-case basis.

In summary the potential in situ remediation of MDA-T constitutes the remediation of an inactive waste site containing buried TRU legacy waste, rather than a current disposal action. Therefore disposal orders and regulations (i.e. DOE Order 435.1, 40 CFR Part 191, and 10 CFR Part 61) are not applicable. They could be applicable if the MDA-T waste were excavated and disposed off-site. While LANL is not listed on the NPL and not currently subject to CERCLA, CERCLA would allow DOE to conduct a CERCLA non-time critical removal action at MDA-T under their own authority with no explicit EPA role. DOE Order 458.1, Radiation Protection of the Public and the Environment, also appears to be an applicable and viable regulatory pathway for DOE's regulation of the potential in situ remediation of the radionuclide components of MDA-T. Therefore the in situ remediation of the radionuclide portion of MDA-T legacy waste could be regulated by DOE through a CERCLA non-time critical removal action, through DOE Order 458.1, or through a combination of both. It is also possible that it could be regulated by DOE through a CERCLA remedial action, although that would likely require greater interaction and integration with NMED 
Table 4. Directive, Order, and Regulation Applicability Overview

\begin{tabular}{|c|c|c|c|}
\hline Directive, Order, and Regulation & Brief Description & Applicable $^{1}$ & Comments / Performance Requirements \\
\hline AEC Immediate Action Directive 0511-21 & $\begin{array}{l}\text { TRU waste to be retrievably stored after April } \\
30,1970\end{array}$ & Yes & $\begin{array}{l}\text { The directive required that no TRU waste be disposal after April 30, 1970, unless } \\
\text { an exception letter is approved by AEC; such an exception letter is not known to } \\
\text { exist }\end{array}$ \\
\hline DOE Order 458.1 & $\begin{array}{l}\text { Radiation protection of public and environment } \\
\text { (replaces DOE 5400.5) }\end{array}$ & Yes & $\begin{array}{l}\text { Performance Requirements: } \\
\text { - Public Dose Limits: TED }<100 \mathrm{mrem} / \mathrm{yr} \text {; ED (eye) }<1500 \mathrm{mrem} / \mathrm{yr} \text {; ED } \\
\text { (skin/ext) }<5000 \mathrm{mrem} / \mathrm{yr} \\
\text { - Air: Rn-222 flux }<20 \rho \mathrm{\rho i} / \mathrm{m}^{2} / \mathrm{s} \text { average through waste cover; Rn-220 \& Rn- } \\
222<3 \mathrm{pCi} / \mathrm{L} \text { at site boundary } \\
\text { - Groundwater: generally taken as }<\text { Maximum Contaminant Levels (MCL) } \\
\text { from } 40 \text { CFR Part } 141 \\
\text { - TRU Waste Disposal: comply with } 40 \text { CFR Part } 191^{3} \\
\end{array}$ \\
\hline DOE Order 435.1 & $\begin{array}{l}\text { Chapter III provides transuranic waste storage, } \\
\text { treatment, and disposal requirements }\end{array}$ & $\sim \mathrm{No}^{4}$ & $\begin{array}{l}\text { Provides the following ways to dispose and regulate TRU waste: } \\
\text { - Degree of isolation } \\
\text { - Case-by-case } 10 \text { CFR Part } 61 \text { approval by the NRC for disposal in a NRC } \\
\text { licensed low-level waste disposal facility } \\
\text { - TSCA and } 435.1 \text { for TRU waste containing TSCA compounds } \\
\text { - RCRA and } 435.1 \text { for Mixed TRU waste } \\
\text { - } 40 \text { CFR Part } 191^{3}\end{array}$ \\
\hline 40 CFR Part 191 & $\begin{array}{l}\text { Provides storage and disposal requirements of } \\
\text { TRU waste disposal after November } 18,1985 \text {. }\end{array}$ & $\mathrm{No}^{5}$ & $\begin{array}{l}\text { Performance Requirements: } \\
\text { - } 10,000 \text { Year Containment: }<10 \% \text { chance to exceed quantities calculated from } \\
\text { Table } 1 \text {, Appendix C; and }<0.1 \% \text { chance to exceed } 10 \text { times the quantities } \\
\text { calculated from Table } 1, \text { Appendix C } \\
\text { - } 10,000 \text { Year Individual Protection: }<15 \mathrm{mrem} / \mathrm{yr} \text {, all pathways } \\
\text { - Alternative provisions allowed based upon costs, risks, benefits, and public } \\
\text { comment }\end{array}$ \\
\hline
\end{tabular}

${ }^{1}$ Applicability relative to DOE's regulation of the potential in-situ remediation of the radionuclide components of the legacy waste at the MDA-T

${ }^{2}$ Public dose limits from all sources and exposure pathways that could significantly contribute to dose at the LANL boundary. The all-pathways total effective dose (TED) and equivalent dose (ED) in $\mathrm{mrem} / \mathrm{yr}$; excludes radon, medical, background \& occupational doses.

${ }^{3}$ Actions to be taken at MDA-T constitute remediation (i.e. corrective action under New Mexico HWA) rather than disposal; therefore 40 CFR Part 191 is not applicable.

${ }^{4}$ Not applicable to remediation of inactive waste sites containing buried TRU waste, unless such remediation results in the storage, treatment, and disposal of TRU waste (i.e. excavation and off-site disposal). However DOE Orders 5820.1, 5820.2, and 5820.2A (see Section 2.0), which were predecessors to DOE Order 435.1, specifically outlined actions to be taken in association with TRU waste, which had been disposed prior to the implementation of these prior orders (i.e. 9/30/82 for DOE Order 5820.1). The actions outlined included monitoring and remedial actions, as necessary. The remedial actions could include in-place remediation or excavation and disposal at WIPP. These previous radioactive waste management orders could be pertinent to the remediation of MDA-T along with the DOE publication referenced by DOE Order 5820.2A (DOE-JIO-025 of 9-87, "Comprehensive Implementation Plan for the DOE Defense Buried Transuranic-Contaminated Waste Program"). More detailed information on DOE Order 5820.2A is provided in Appendix C.

${ }^{5} 40$ CFR Part 191 is not applicable because it does not apply to waste disposed of before November 18, 1985. Additionally it is not applicable to the remediation of inactive waste sites containing buried TRU waste, unless that remediation involves the excavation and off-site disposal of the TRU waste. 


\begin{tabular}{|c|c|c|c|}
\hline Directive, Order, and Regulation & Brief Description & Applicable $^{1}$ & Comments / Performance Requirements \\
\hline 40 CFR Part 300 (CERCLA) & Remediation of Superfund Sites (NPL Sites) & Potentially $^{6}$ & $\begin{array}{l}\text { Performance Requirements: } \\
\text { - Lifetime Excess Cancer Risk between } 10^{-4} \text { and } 10^{-6} \text { for carcinogens } \\
\text { - Hazards Index }(\mathrm{HI})<1 \text { for non-carcinogens }\end{array}$ \\
\hline 10 CFR Part 61 (NRC) & $\begin{array}{l}\text { Land Disposal of radioactive waste, for NRC } \\
\text { licensed sites }\end{array}$ & $\mathrm{No}^{7}$ & $\begin{array}{l}\text { Performance Requirements: } \\
\text { - All-pathway }<25 \mathrm{mrem} / \mathrm{yr} \text { to whole body } \\
\text { - All-pathway }<75 \mathrm{mrem} / \mathrm{yr} \text { to thyroid } \\
\text { - All-pathway }<25 \mathrm{mrem} / \mathrm{yr} \text { to other organs }\end{array}$ \\
\hline
\end{tabular}

${ }^{6}$ LANL is not listed on the NPL; therefore MDA-T is not currently subject to CERCLA. However under CERCLA, DOE could conduct CERCLA non-time critical removal action of MDA-T under their own authority with no explicit EPA role.

${ }^{7}$ MDA T is not a NRC licensed site, and the only way that 10 CFR Part 61 could potentially be applicable to MDA-T is if the MDA-T TRU waste were excavated and disposed within an NRC licensed low-level waste disposal facility, if approved by NRC on a case-by-case basis. 


\subsection{Key Technical Uncertainties}

Key technical uncertainties of interest for the selection of a path forward include:

1) What is the basis for the determination that TRU waste was disposed within the MDA-T shafts up through 1975? Is it based on the original waste water concentrations or on the final grout concentrations? Is it possible that in its current condition that it would no longer be classified as TRU? Is it likely that upon possible excavation and the resultant blending that would occur that it would no longer be classified as TRU?

2) Is there anything associated with the legacy waste that would not meet the waste acceptance criteria for WIPP? For a retrieval option, it is undesirable to create a waste stream with no path for disposal.

3) Efforts to locate any evidence that an exception to IAD 0511-21 exists in the historical records have been unsuccessful. Although, based on efforts to date, it does not seem likely that documentation of an exception exists, if found, it would be an acceptable basis for the decision to dispose of waste in the shafts after 1970.

4) There is a need for consistency, as appropriate, for regulatory decisions across the LANL site. It will be important to consider how the proposed regulatory options for MDA-T compare with the regulatory options applied at other locations at LANL. Especially, it is important to know if disposal standards have been applied to corrective actions at other LANL locations or not.

5) 40 CFR Part 191 only applies to TRU waste disposed after the effective date in 1985. Thus, the TRU waste in the shafts is not legally bound by 40 CFR Part 191, since TRU waste was disposed in the shafts only up through 1975. However, for an option that involves leaving the waste in place, would DOE (and/or other applicable organizations) expect the containment and performance objectives in 40 CFR Part 191 to be met or will it be sufficient to meet the criteria in DOE Order 458.1 regarding protection of human health and the environment. It seems that a strict legal interpretation would suggest that the standards in DOE Order 458.1 should be applied.

6) Protectiveness of the selected option will be a critical consideration. Will it be possible to meet the performance objectives of DOE Order 458.1 (or, if deemed necessary, 40 CFR Part 191 or DOE Order 435.1 for low-level waste) if the legacy waste is left in place? This will depend on a number of specific technical factors, many of which were identified in the questions in Appendix B. A key factor will be how much credit can be taken for the integrity of the waste form and what is known about the properties of the waste as disposed. The ability to take credit for isolation of the waste and to defend assumptions about the waste form will be a critical factor in any modeling conducted to defend a decision to leave the waste in place. Some key considerations include:

a. What is known about the condition of the grouted waste in the shafts and how much credit can be defensibly taken for the waste form in terms of limiting releases to the environment? 
b. What engineered features were included in the shafts (asphalt or concrete lining at the base and on the walls, plugs on the surface, etc.) and how much credit can be taken for the isolation capability?

c. What is the expected effectiveness of potential remedial measures (cut off walls, sheet piles, covers, etc.) and how much credit can be taken for their effectiveness?

d. Is there evidence of migration from the waste in the shafts?

7) What are the potential risks/health effects associated with excavating, characterizing, and repackaging the legacy waste prior to transporting it to another disposal location? Protection of human health and the environment must be assured for that option as well.

8) Defensible cost estimates for retrieval versus leaving the legacy waste in place. Cost will be another factor in the decision making process, thus defensible estimates will be needed.

9) If it is determined that DOE Order 458.1 should form the regulatory framework for DOE's authority over the radionuclide components of the MDA-T legacy waste, what process will be followed to apply DOE Order 458.1 remedial action objectives for this corrective action? DOE Order 458.1 establishes remedial action objectives, but does not specify the process to demonstrate that those objectives are met for a specific action. Would a process similar to that applied for assessments conducted for LLW disposal be sufficient (i.e., LFRG review process)? Additionally what EPA or NMED involvement is appropriate and/or necessary, if any, and how should DOE's regulation of the radiological portion of MDA-T be integrated with the NMED/LANL Consent Order requirements (see Section 4.0) for the hazardous waste portion of MDA-T legacy waste?

10) If it is determined that DOE's CERCLA non-time critical removal action or remedial action authority should form the regulatory framework over the radiological portion of MDA-T legacy waste, the following items would need to be considered:

a. What remedial action objective or combination of objectives should be applied to the radionuclide fraction of the waste (DOE 458.1, 40 CFR Part 191, DOE Order 435.1 for low-level waste, or typical CERCLA risk criteria (i.e. $10^{-4}$ to $10^{-6}$ lifetime excess cancer risk and a hazard index (HI) of one))?

b. What process will be followed to apply the selected remedial action objectives for this corrective action? Would a process similar to that applied for assessments conducted for LLW disposal be sufficient (i.e., LFRG review process)?

c. What EPA or NMED involvement is appropriate and/or necessary, if any, and how should DOE's regulation of the radiological portion of MDA-T legacy waste be integrated with the NMED/LANL Consent Order requirements (see Section 4.0) for the hazardous waste portion of MDA-T legacy waste? 
These uncertainties should be addressed during further evaluation of the available regulatory options for a path forward for MDA-T. Addressing these uncertainties should help to clarify the viability and relative merits of different options. 


\subsection{Review of Potential Pathways Developed by LANL}

LANL personnel have several regulatory scenarios for the two alternative considered for TRU legacy waste at MDA-T: excavation and WIPP disposal, and in situ remediation (Figure3). Excavation and WIPP disposal already has a well defined DOE regulatory pathway and does not require further evaluation.

Per the degree-of-isolation exception discussed in DOE Order 435.1, LANL's Regulatory Path 1 would establish an exception that removes these legacy wastes from the TRU waste definition based on an evaluation of the proposed disposal concept. Presumably this would result in the waste being reclassified as low-level waste and would form the basis for not shipping the waste to WIPP along with a preliminary radiological impact analysis, that the proposed disposal concept of in situ remediation is protective of human health and the environment. Presumably, the radiological exposure analysis would need to show protection equivalent to the performance objective of DOE Order 435.1. The exception basis and radiological impact analysis must be approved by the DOE Secretary, who then sends it to the EPA Administrator for concurrence. This dual approval at such high levels is perceived as a significant hurdle to a degree-of-isolation exception in terms of both effort and time. Additionally given that the Implementation Guide for DOE Order 435.1 suggests that the degree-of-isolation exception is applicable to a small volume of waste and low curie amount, which is undefined in the guide, it is unlikely that this path is viable for the estimated 3,600 cubic meters and 4,000 Ci of TRU legacy waste in the MDA-T shafts (volume estimate from Table 3 in DOE 2000).

Regulatory Path 2 would follow the requirements in 40 CFR Part 191 to show TRU legacy waste isolation at MDA-T is equivalent to the WIPP site, but EPA review and concurrence are not required because 40 CFR part 191 applies to disposal of TRU waste after November 1985. However, review and approval would have to be authorized by DOE Headquarters, presumably by the Assistant Secretary for Environmental Management and the Director of the Office of Health, Safety, and Security. This path is not applicable to MDA-T in situ remediation, because the waste was disposed prior to the implementation of 40 CFR Part 191 and it is a remedial action and not a disposal action. Also, if this path is followed, demonstrating compliance with the requirements of 40 CFR Part 191 via a performance analysis/composite analysis and independent review are likely to extend beyond the present milestone of February 11, 2015 for the RCRA Remedy Completion Report. Finally the containment requirement of 40 CFR Part 191, could prove problematic.

Since the waste has already been disposed and this is a corrective action, Regulatory Path 3 to develop a new disposal standard would not be relevant unless the waste was to be excavated and disposed again. Also, similar to the time constraint identified for Regulatory Path 2, there is a very low probability that new rulemaking on an alternative disposal standard for TRU waste (Regulatory Path 3) could be drafted, reviewed, put out for public comment, revised, and promulgated prior to the RCRA milestone identified above. Further such an effort would be expensive and should probably only be 
considered as a last resort, if no other applicable and viable regulatory pathway can be identified.

Regulatory Path 4 is divided into two options: CERCLA (Path 4a) and DOE Order 458.1 (replaces DOE 5400.5, Path 4b). Under CERCLA, DOE can conduct CERCLA non-time critical removal actions under their own authority with no explicit EPA role even at nonNPL sites such as MDA-T. Such removal actions require an Engineering Evaluation / Cost Analysis (EE/CA), public involvement, and potentially review by EPA's National Remedy Review Board (NRRB). In a typical CERCLA action, human risk is addressed through an evaluation of carcinogenic (non-radiogenic and radiogenic) and noncarcinogenic contaminants, which is substantially different and more time consuming than the established DOE protocols for assessing dose from radiogenic contaminants (e.g., DOE Order 458.1). Additionally, the CERCLA approach may introduce confusion with the state regulators over integration of CERCLA and RCRA requirements. Use of CERCLA remedial action authority at a non-NPL RCRA regulated site, such as LANL, would likely require integration of the full CERCLA process for radionuclides with the with the existing RCRA process for hazardous waste components. In the case of LANL this would likely require an agreement between DOE and NMED regarding such integration and would possibly require a modification of the NMED/LANL Consent Order. It is likely that the interaction and integration that would be required for a CERCLA remedial action would extend beyond the present milestone of February 11, 2015 for the RCRA Remedy Completion Report. (EPA 1993, EPA/DOE/DOE 1994, and DOE/EPA1995)

For Regulatory Path 4b, DOE Order 458.1 identifies objectives for protection of human health and the environment for remedial actions that would apply to the waste at MDA-T (see Table 4). The disposal aspects of DOE Order 458.1 do not apply, because MDA-T is a remedial or corrective action, not a disposal action. As DOE Order 458.1 is not prescriptive on how to comply with the order, sampling or modeling can be used to demonstrate that the requirements are met. Modeling performed to demonstrate compliance with DOE Order 458.1 could consider the approaches in DOE Order 435.1 for low-level waste disposal as a guideline. 


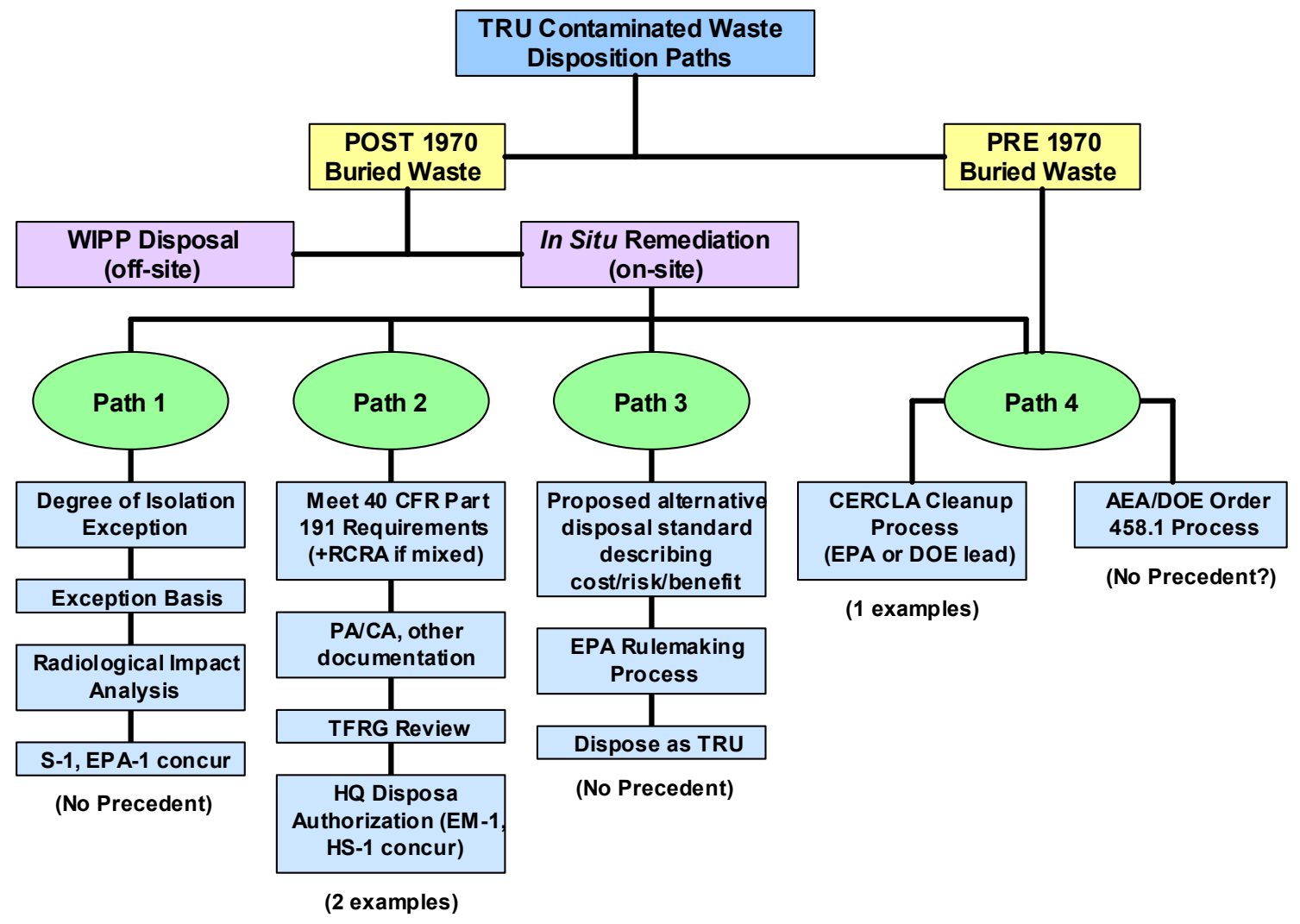

Figure 3. Potential TRU disposition pathways identified by LANL. 


\subsection{Recommendations}

For the in situ remediation paths on Figure 3, two key assumptions underpin the recommendations for the most applicable and viable regulatory pathway for DOE regulation of the radiological portion of MDA-T legacy waste:

- The legacy TRU waste in the MDA-T vertical Disposal Shafts was emplaced as a cementitious waste form, which was considered permanent disposal at the time of emplacement rather than temporary storage for future retrieval.

- The present in situ remediation path analysis for MDA-T deals with future in situ remedial actions and not future excavation and disposal actions.

A higher degree of credibility could be assigned to the recommendations if an exception letter to AEC IAD 0511-21 exists, because its existence would unequivocally defend the in situ remedial action position and eliminate the discussion on whether the post-1970 TRU disposal actions (up through 1975) at MDA-T were formally sanctioned. It is recommended that the LANL historian's office research whether such a LANL exception exists and when LANL actually received AEC IAD 0511-21.

Given the above assumptions and time constraint of February 2015, the review team recommends that the in situ remediation of the radionuclide portion of MDA-T legacy waste follow one of the following two DOE regulatory pathways:

- DOE Order 458.1 (Path $4 b$ on Figure 3), or

- CERCLA non-time critical removal actions under DOE authority

Consultation with staff in EM-41 and HS-22 should be held regarding:

1) Which DOE regulatory pathway should be pursued (i.e. either DOE Order 458.1, 40 CFR Part 300.415 (CERCLA removal action), or both),

2) The applicable performance objective associated with the preferred DOE regulatory pathway, and

3) A process to address the applicable performance standards versus the MDA-T in situ remedial action.

The in situ remedial action performance objective or combination of objectives applied to the radionuclide fraction of the MDA-T waste could come from one or a combination of DOE 458.1, 40 CFR Part 191, or 40 CFR Part 300 (CERCLA) (see Table 4).

Additionally DOE Order 435.1 performance objectives for low-level waste could also be considered. The process to be followed to apply the selected performance objectives to this in situ corrective action could be a process similar to that applied for assessments conducted for LLW disposal (i.e., LFRG review process). If DOE Order 458.1 were to be utilized as the regulatory pathway, clarification concerning the appropriate method of considering cumulative impacts (i.e., adjacent facilities and waste sites that could interact with transport from MDA-T) would need to be addressed to fully comply with DOE 
Order 458.1. Finally based upon the regulatory pathway chosen, a determination of whether EPA and/or NMED involvement is appropriate and/or necessary, and how DOE's regulation of the radiological portion of MDA-T legacy waste should be integrated with the NMED/LANL Consent Order requirements (see Section 4.0) for the hazardous waste portion of MDA-T legacy waste should be made. Scoping meetings involving appropriate regulatory agencies has proved effective at other DOE sites in the resolution of such issues.

The technical uncertainties outlined in Section 7.0 should be addressed to help further clarify the viability and relative merits of these different regulatory options. The recommendations outlined below will help answer some of the Section 7.0 technical uncertainties.

Scoping calculations should be performed to assess the impacts of leaving the legacy waste in place, and these informal evaluations should compare the results to the performance objectives in DOE Order 458.1, 40 CFR 191, DOE Order 435.1 (low-level waste), and 40 CFR Part 300 (CERCLA), as appropriate, to gain perspective on the relative importance of assumptions regarding the waste form and any engineered features. Although 40 CFR 191 does not apply to remedial actions, it is considered worthwhile to take a look at what requirements can be met (e.g., the 40 CFR 191.15 requirement for individual exposure to be less than $15 \mathrm{mrem} / \mathrm{yr}$ all pathways). Careful consideration should go into the defense of assumptions used to demonstrate compliance with the selected performance objectives.

The WIPP alternative on Figure 3 accounts for the option to exhume, characterize, repackage, and dispose of the waste at WIPP. Presently, there is insufficient information on the physical form of some waste components and the fission inventory to determine if the waste in the MDA-T shafts will meet the WIPP Waste Acceptance Criteria (WAC). Prior to any administrative action that considers exhuming the waste, it is recommended that LANL meet with WIPP waste representatives to discuss the physical, chemical and inventory properties of the waste to determine if the waste will meet the WIPP WAC. If the legacy waste is shown to not meet the WIPP WAC, then the in situ remedial option with the associated regulatory pathways discussed herein would become the sole viable option. If the waste is shown to meet the WIPP WAC, the selection of this path will require that risks be assessed for radiation exposure and safety incidents during excavation, handling, packaging, and transportation of the waste. At a minimum, it is recommended that a risk and cost analysis be performed to demonstrate that retrieval of the waste and shipment to WIPP is more beneficial to DOE than in situ remediation of MDA-T. 


\subsection{References}

Bearzi, J. P. 2010. List of Documents Subject to Stipulated Penalties under the March 1,2005 Consent Order for Federal Fiscal Year 2011 Los Alamos National Laboratory, EPA ID\#NM0890010515, HWB-LANL-MISC, Letter to George Rael and Michael Graham, New Mexico Environment Department, Hazardous Waste Bureau, July 15, 2010 .

DOE-JIO-025 of 9-87, "Comprehensive Implementation Plan for the DOE Defense Buried Transuranic-Contaminated Waste Program," describes long term management alternatives for all DOE sites with buried transuranic waste.

DOE/EPA 1995. Policy on Decommissioning Department of Energy Facilities under CERCLA, Memorandum from Steven A. Herman (EPA), Elliot P. Laws (EPA), and Thomas P. Grumbly (DOE) to addressees, Department of Energy / Environmental Protection Agency. May 22, 1995.

(www.epa.gov/fedfac/documents/decommissioning_doe.htm)

DOE/EPA 1998. Review of Department of Energy Non-Time-Critical Removal Actions by the National Remedy Review Board, Memorandum from James j. Fiore (DOE), James E. Woolford (EPA), and Stephen D. Luftig (EPA), Department of Energy / Environmental Protection Agency. October 5, 1998.

DOE 2008. Final Site-Wide EIS for Continued Operation of Los Alamos National Laboratory, Los Alamos, New Mexico, Volume 2, Book 2, Appendix I Major Material Disposal Area Remediation, Canyon Cleanups, and Other Consent Order Actions, DOE/EIS-0380, United States Department of Energy, May 2008.

DOE, 2000. Buried Transuranic-Contaminated Waste Information for U.S. Department of Energy Facilities, DOE Office of Environmental Management, Washington, D.C.

EPA 1993. Conducting Non-Time-Critical Removal Actions under CERCLA, EPA/540/F-94/009, Environmental Protection Agency, Washington, DC. December 1993.

EPA/DOE/DOD 1994. Guidance on Accelerating CERCLA Environmental Restoration at Federal Facilities, Memorandum from Steven A. Herman (EPA), Elliot P. Laws (EPA), Thomas P. Grumbly (DOE), and Sherri W. Goodman (DOD) to addressees, Environmental Protection Agency / Department of Energy / Department of Defense. August 22, 1994. (www.epa.gov/fedfac/documents/822memo.htm)

FFA (Federal Facilities Agreement). 1993. Federal Facilities Agreement for the Savannah River Site, Administrative Document Number 89-05-FF (Effective Date: August 16, 1993). 
Graham, M. J. and Rael, G. J. 2010. Revised Request for Extension to Submit the Material Disposal Area T Remedy Completion Report, Letter to James Bearzi (NMED), EP2010-0341, Los Alamos National Laboratory, Los Alamos, New Mexico, July 16, 2010.

LANL 2006. Investigation Report for Material Disposal Area T, Consolidated Unit 21016(a)-99, at Technical Area 21, LA-UR-06-6506 (EP2006-0779), Los Alamos National Laboratory, September 2006

LANL 2009. Phase III Investigation Report for Material Disposal Area $T$ at Technical Area 21, LA-UR-09-5805 (EP2009-0455), Los Alamos National Laboratory, September 2009

LANL 2011. MDA-T Slides Rad Regulatory Path Forward 03-01-11

LASL 1974. Guidelines for the Interim Storage of AEC-Generated Solid Transuranic Wastes, LA-6545, Los Alamos Scientific Laboratory, June 1974

NMED 2005. NMED/LANL Compliance Order On Consent, State Of New Mexico Environment Department, March 1, 2005.

NMED 2008. NMED/LANL Compliance Order On Consent, State Of New Mexico Environment Department, Revision 1, June 18, 2008.

Travers, J., Alexandrova, E., and Resnikoff, M. 2009. An Assessment of Los Alamos National Laboratory Waste Disposal Inventory Los Alamos, New Mexico, Radioactive Waste Management Associates, 526 West 26th Street \# 517, New York, NY 10001. November, 2009.

\section{Directives, Orders, and Regulations}

10 CFR Part 61, Licensing Requirements For Land Disposal Of Radioactive Waste (NRC) (http://ecfr.gpoaccess.gov/cgi/t/text/text$\underline{\mathrm{idx}} \mathrm{c}=\mathrm{ecfr} \& \mathrm{sid}=0 \mathrm{dfd} 4 \mathrm{~b} 272 \mathrm{bf} 2192168 \mathrm{e} 5 \mathrm{da} 6 \mathrm{c} 53 \mathrm{~d} 65309 \& \mathrm{rgn}=\mathrm{div} 5 \& \mathrm{view}=$ text\&node $=10$ $: 2 \cdot 0 \cdot 1 \cdot 1.7 \&$ idno $=10$ )

10 CFR Part 830, Nuclear Safety Management (DOE) (http://ecfr.gpoaccess.gov/cgi/t/text/textidx?type $=$ simple $; c=$ ecfr; $c c=$ ecfr; $;$ id $=0 \mathrm{dfd} 4 \mathrm{~b} 272 \mathrm{bf} 2192168 \mathrm{e} 5 \mathrm{da} 6 \mathrm{c} 53 \mathrm{~d} 65309 ;$ idno=10;regi on=DIV $1 ; q 1=830 ;$ rgn= div5; view=text;node=10\%3A4.0.2.5.26)

10 CFR Part 835, Occupational Radiation Protection (DOE) (http://ecfr.gpoaccess.gov/cgi/t/text/text$\mathrm{idx} ? \mathrm{c}=$ ecfr\&sid $=0 \mathrm{dfd} 4 \mathrm{~b} 272 \mathrm{bf} 2192168 \mathrm{e} 5 \mathrm{da} 6 \mathrm{c} 53 \mathrm{~d} 65309 \& \mathrm{rgn}=\mathrm{div} 5 \& \mathrm{view}=$ text\&node $=10$ $: 4 \cdot 0.2 \cdot 5 \cdot 27 \& \mathrm{idno}=10$ ) 
20 NMAC 4.1, Hazardous Waste Management (New Mexico Hazardous Waste Act (HWA)) (http://ecfr.gpoaccess.gov/cgi/t/text/text$\mathrm{idx} ? \mathrm{c}=$ ecfr\&sid=0dfd4b272bf2192168e 5 da6c53d65309\&rgn $=$ div $5 \&$ view $=$ text $\&$ node $=10$ $: 4 \cdot 0 \cdot 2 \cdot 5 \cdot 27 \& \mathrm{idno}=10$ )

40 CFR Part 191, Environmental Radiation Protection Standards For Management And Disposal Of Spent Nuclear Fuel, High-Level And Transuranic Radioactive Wastes (EPA) (http://ecfr.gpoaccess.gov/cgi/t/text/text$\underline{\mathrm{idx}} \mathrm{c}=\mathrm{ecfr} \& \mathrm{sid}=0 \mathrm{dfd} 4 \mathrm{~b} 272 \mathrm{bf} 2192168 \mathrm{e} 5 \mathrm{da} 6 \mathrm{c} 53 \mathrm{~d} 65309 \& \mathrm{rgn}=\mathrm{div} 5 \& \mathrm{view}=$ text\&node $=40$ $: 24 \cdot 0.1 .1 .2 \& \mathrm{idno}=40$ )

40 CFR Part 264, Standards for Owners and Operators of Hazardous Waste Treatment, Storage, and Disposal Facilities (RCRA) (http://ecfr.gpoaccess.gov/cgi/t/text/text$\underline{\mathrm{idx}} \mathrm{c}=\mathrm{ecfr} \& \mathrm{sid}=\mathrm{c} 3183 \mathrm{a} 6 \mathrm{~d} 31810 \mathrm{aeb} 60 \mathrm{~b} 03 \mathrm{a} 47 \mathrm{c} 2513814 \& \mathrm{rgn}=\mathrm{div} 5 \& \mathrm{view}=$ text\&node $=40$ $: 25.0 .1 .1 .5 \&$ idno $=40$ )

40 CFR Part 265, Interim Status Standards for Owners and Operators of Hazardous Waste Treatment, Storage, and Disposal Facilities (RCRA) (http://ecfr.gpoaccess.gov/cgi/t/text/text$\mathrm{idx} ? \mathrm{c}=$ ecfr\&sid $=\mathrm{c} 3183 \mathrm{a} 6 \mathrm{~d} 31810 \mathrm{aeb} 60 \mathrm{~b} 03 \mathrm{a} 47 \mathrm{c} 2513814 \& \mathrm{rgn}=\mathrm{div} 5 \& \mathrm{view}=$ text\&node $=40$ $: 25.0 .1 .1 .6 \&$ idno $=40$ )

40 CFR Part 300, National Oil And Hazardous Substances Pollution Contingency Plan (CERCLA) (http://ecfr.gpoaccess.gov/cgi/t/text/text$\mathrm{idx} ? \mathrm{c}=\mathrm{ecfr} \& \mathrm{sid}=0 \mathrm{dfd} 4 \mathrm{~b} 272 \mathrm{bf} 2192168 \mathrm{e} 5 \mathrm{da} 6 \mathrm{c} 53 \mathrm{~d} 65309 \& \mathrm{rgn}=\mathrm{div} 5 \& \mathrm{view}=$ text $\&$ node $=40$ $: 27.0 .1 .1 .1 \&$ idno $=40$ )

AEC, 1970, "Policy Statement Regarding Solid Waste Burial," Immediate Action Directive No. 0511-21, U.S. Atomic Energy Commission. 3/20/1970.

AEC, 1973, "Radioactive Waste Management", AEC Manual, Chapter 0511, U.S. Atomic Energy Commission. 9/19/1973.

DOE O 435.1, Radioactive Waste Management, Change 1, 8/28/2001. (Current and archived DOE Directives can be found at the following web address: https://www.directives.doe.gov/directives/current-directives)

DOE M 435.1-1, Radioactive Waste Management Manual, Change 1, 6/19/2001.

DOE G 435.1, Implementation Guide, 7/9/1999.

DOE Order 458.1, Radiation Protection of the Public and the Environment, 02/11/2011.

DOE Order 5400.5, Radiation Protection of the Public and the Environment, Change 2, 1/7/1993. 
DOE Order 5480.2, Hazardous and Radioactive Mixed Waste Management, 12/13/1982.

DOE Order 5820.1, Management of Transuranic Contaminated Materials, 9/30/1982.

DOE Order 5820.2, Radioactive Waste Management, 2/6/84.

DOE Order 5820.2A, Radioactive Waste Management, 9/26/88.

NMED 2011. NMED Hazardous Waste Bureau web site for the LANL Hazardous Waste Permit (EPA ID\#: NM0890010515; NM ID\#: 2390)

(http://www.nmenv.state.nm.us/hwb/lanlperm.html\#LANL\%20FFCO) 


\title{
Appendix A \\ Independent Technical Review Team \\ Technical Assistance Request
}

\author{
U.S. Department of Energy \\ Office of Environmental Management
}

\section{The EM Center for Sustainable Groundwater Solutions at the Savannah River National Laboratory}

\section{Project Title:}

Remediation of Material Disposal area T, Technical Area 21, at Los Alamos Natif

\section{Contact Information from Requesting Site}

DOE - SITE Los Alamos National Laboratory

Site Manager George Rael

EM Office Director: Kurt Gerdes, DOE-EM

Point of Contact Information (Contractor Program Manager)

Name of Requestor Paul Huber (505) 412-7673

Site/Operable Unit Ed Worth

Telephone Number (505) 606-0398

Email Address eworth@doeal.gov

2. Project Information Location

MDA T, Technical Area 21, Los Alamos, New Mexico

Description of the Requested Technical Solution:

In 1970, the AEC promulgated Immediate Action Directive 0511-21 that required that shallow land burial of transuranic (TRU) wastes be discontinued, and that such wastes be maintained in a "readily retrievable" configuration, pending the availability of a geologic repository (which we recognize today as the WIPP facility in southeastern New Mexico).

This directive has been followed for the most part by all DOE sites, including LANL. However, LANL as well as at least one other major generator site, disposed of TRU waste in shafts some 13 years after the AEC directive (through about 1983).

EPA 40 CFR Part 191, which governs the disposal of TRU waste, became effective in 1985.

The key issue explored here is whether a radiological impact analysis against the EPA 40 CFR Part 191 standards is needed by DOE to effectively evaluate and demonstrate regulatory control of the subject TRU waste disposal, in view of the fact that the disposals occurred after 1970, but before the effective date of the EPA rule. 
Additional Narrative, Information, and Applicable References

3. Schedule:

Date Event

$\square$ 05/06/2011 White paper report with recommendations

$\square$

$\square$

$\square$

$\square$

$\square$

Email completed request form to:

Robert (Bob) Aylward - SRNL

Kurt Gerdes - DOE-EM

robert.aylward@srnl.doe.gov

kurt.gerdes@em.doe.gov 


\title{
Appendix B \\ Savannah River National Laboratory (SRNL) Considerations/Questions for Material Disposal Area T Remedial Alternative
}

\author{
Mark Phifer, Roger Seitz, and Elmer Wilhite \\ October 1, 2010
}

The following considerations/questions would provide useful information for the evaluation of Material Disposal Area T (MDA-T) remedial alternatives. While this information would be useful, not all of it may be readily available. Some of the more important considerations/questions are highlighted in yellow.

\section{$\underline{\text { Regulatory Considerations/Questions }}$}

- What EPA, New Mexico Environmental Department (NMED), and DOE regulations or orders apply to the consideration of MDA-T remedial alternatives?

- What was the waste classification as disposed (was it considered TRU or LLW; was it hazardous or non-hazardous from a RCRA perspective)?

- What is the regulatory significance of the presence of volatile organics/tritium within the vadose zone in relation to MDA-T remedial alternatives?

- Are there classified materials or characteristics that could be a concern?

- What is the current proposed closure plan or remedial action?

- Some more details regarding each disposal shaft would be helpful in regards to regulatory issues:

- Dates for start and end of disposal for each shaft or at least identifying all shafts that were operated after 1970, if TRU waste is involved (regulatory significance)

- Depth below ground surface for the top and bottom of waste in each shaft (important for intruder)

- It appears that the cementitious waste in corrugated metal pipes, which was stored in the Retrievable Waste Storage Area (RWSA) between Absorption Beds 1 and 3, has been removed from MDA-T and relocated to MDA-G. Is this correct?

\section{Safety Considerations/Questions}

- Are there hazards associated with volatile organics/tritium or dose in MDA-T that would pose significant worker concerns, if the waste was to be excavated?

- How would ALARA be addressed if the waste is to be excavated? 


\section{Disposal Considerations/Questions}

- Are there any characteristics of the waste in the shafts and absorption beds that would preclude disposal at WIPP (any showstoppers, such as the final waste form not being TRU, non-defense related or other prohibited characteristics)?

- If removal of the waste is required for regulatory reasons, would it be possible to auger the waste out of the disposal shafts rather than excavating the entire area?

\section{$\underline{\text { Technical Considerations/Questions }}$}

- Were the disposal shafts installed entirely within the Bandelier Tuff? If not what other formations/materials were the shafts installed within? Was any soil overburden removed prior to installation of the shafts

- What are the physical and hydraulic properties (e.g., compressive strength, bulk density, porosity, hydraulic conductivity/saturation/matrix potential) of the Bandelier Tuff and/or other formations/materials?

- It appears that approximately 63 disposal shafts were augered. Of the 63 disposal shafts 14 are 6 foot diameter and 49 are 8 foot diameter. The depths of the shafts from the original ground surface range from 15 to 69 feet. It further appears that the shafts were coated with asphalt prior to use, but not cased. Is this information correct?

- What was the determining factor for the depth to which each disposal shaft was augered? Was it a constructability issue where each shaft was augered to the depth of refusal?

- Were the disposal shaft bottoms plugged, with anything other than asphalt, prior to introduction of the cementitious waste form? If so what material was used and how thick was it?

- Were the tops of the individual disposal shafts capped? If so what material was used and how thick was it?

- Were the disposal shafts collectively capped or covered? If so what is the design of the current cover (materials, thicknesses, slopes, etc.)? Is it simply a sloped soil cover?

- Is the following information documented for each disposal shaft? If so can that information be consolidated and made available?

- Center coordinates

- Diameter

- Bottom elevation

- Top elevation of cementitious waste form

- Current surface elevation

- Waste volume

- Waste bulk density

- Total inventory of radionuclides and other contaminants of concern, including those that could impact radionuclide migration (e.g., chelating agents)

- Average concentration of radionuclide in nano-curies per gram

- Presence of any solids in addition to the cementitious waste form (e.g., Bathyspheres) 
- What construction techniques are currently available to perform the following in association with the Bandelier Tuff and/or other pertinent formations/materials:

- The excavation of trenches for cut-off walls (to what depth can trenches be dug and would muds be required to keep the trenches open?)

- The installation of sheet piles (to what depth can sheet piles be driven?)

- Is the following information documented for the cementitious waste form? If so can that information be made available?

- Chemical composition of the treated liquid waste (including organic and inorganic chemical concentrations in addition to radionuclide concentrations) that was mixed with cement to produce the cementitious waste form (certain chemical compositions, particularly some organics can impact cement setting (i.e. hydration))

- Formulation of the cementitious waste form (i.e. type and amount (lbs/cu yd) of cement; water-to-cement ratio; amount (lbs/cu yd) of sand, if included in the formulation; etc.)

- Testing and QA/QC associated with cementitious waste form formulation development and production for placement within the disposal shafts (i.e. material proportioning/mixing, production of bleed water, compressive strength, bulk density, etc.)

- Method of cementitious waste form placement within the disposal shafts

- What is known about the current state of the cementitious waste form?

- Would it be possible to conduct CPT or blow counts within selected disposal shafts (i.e. relatively low radionuclide inventory and does not contain solids such as Bathyspheres) in order to obtain information on the current state of the cementitious waste form, in particular in relation to the strength of the cementitious waste form?

- Is it believed that the bulk of the radionuclides disposed currently remain within the disposal shafts and absorption beds or has significant radionuclide migration occurred? What evidence is available to make such a determination?

- What is the annual precipitation, evapotranspiration, runoff, and infiltration average and range associated with the MDA-T location? 


\section{Appendix C \\ Overview of Directives, Orders, and Regulations Potentially Pertinent to Material Disposal Area T TRU Waste Remediation}

Currently remediation of the hazardous waste components of the legacy waste at the Material Disposal Area T (MDA-T) are regulated by the New Mexico Environment Department (NMED) through the New Mexico Hazardous Waste Act (HWA) under the Resource Conservation and Recovery Act (RCRA) authorization for the Environmental Protection Agency to the Sate of New Mexico, as outlined below and within Section 4.0. Remediation of the radionuclide components, including transuranic (TRU) waste, of the legacy waste at the MDA-T are subject to Department of Energy (DOE) authority under a yet to be determined regulatory framework. Potentially pertinent directives, orders, and regulations are reviewed below relative to their applicability to DOE's authority to regulate potential in situ remediation of the radionuclide components of the legacy waste at the MDA-T. Ex situ remediation (i.e. excavation and WIPP disposal) already has a well defined DOE regulatory pathway and does not require further evaluation.

20 NMAC 4.1, Hazardous Waste Management (New Mexico Hazardous Waste Act (HWA)) (related EPA regulations: 40 CFR Part 264, Standards for Owners and Operators of Hazardous Waste Treatment, Storage, and Disposal Facilities (RCRA); and 40 CFR Part 265, Interim Status Standards for Owners and Operators of Hazardous Waste Treatment, Storage, and Disposal Facilities (RCRA))

\section{Scope:}

Requirements for hazardous waste generation, storage, disposal and corrective action.

\section{Applicability:}

The state of New Mexico received a RCRA authorization from EPA to implement its Hazardous Waste Act in lieu of RCRA on January 25, 1985. Further, the state received EPA authorization to implement its HWA corrective action program on January 2, 1996 (NMED, 2005; NMED 2008). Title 20, Environmental Protection, Chapter 4, Hazardous Waste, Part 1, Hazardous Waste Management has incorporated 40 CFR Parts 264 and 265 by reference as stated within the following sections of the HWA, including the corrective action provisions of 264.100, 264.101, and Subpart S:

- 20.4.1.500 Adoption of 40 CFR Part 264. Except as otherwise provided, the regulations of the EPA set forth in 40 CFR Part 264 through July 1, 2008 are hereby incorporated by reference.

- 20.4.1.600 Adoption of 40 CFR Part 265. Except as otherwise provided, the regulations of the EPA set forth in 40 CFR Part 265 through July 1, 2008 are hereby incorporated by reference. 
A NMED/LANL Consent Order, pursuant to the HWA (NMSA 1978, 74-4-10) and to the New Mexico Solid Waste Act (SWA) (NMSA 197874-9-36(D)) was entered into by the NMED, DOE, and the University of California (UC) and became effective March 1, 2005. On June 18, 2008, the Order was modified to add Section IV.A.g, which covers the notification requirements for groundwater monitoring results and to make revisions to the deliverables (NMED 2005; NMED 2008).

Specifics of the NMED/LANL Consent Order as it applies to remediation of MDA-T are outlined within Section 4.0.

\section{Performance Requirements:}

NMED has established the following cleanup levels for remediation of LANL waste sites included in the NMED/LANL Consent Order (NMED 2005; NMED 2008), including MDA$\mathrm{T}$ :

- In general, consistent with the EPA's National Oil and Hazardous Substance Pollution Contingency Plan, 40 C.F.R. $\$ 300.430(e)(2)(i)(A)(2)$, the NMED has selected a target human health lifetime excess cancer risk level of $10^{-5}$ or a hazard index (HI) level of one as cleanup goals for establishing site-specific cleanup levels for one or more contaminants for which toxicological data are published.

- The WQCC groundwater standards, including alternative abatement standards (20.6.2.4103 NMAC), and the drinking water maximum contaminant levels (MCLs) adopted by EPA under the federal Safe Drinking Water Act (42 U.S.C. $\S \S 300$ f to $300 \mathrm{j}-26)$ or the EIB (20.7.10 NMAC) are cleanup levels for groundwater. If both a WQCC standard and an MCL have been established for an individual substance, then the lower of the two levels will be considered the cleanup level for that substance.

- NMED has specified soil-cleanup levels that are based on a target total excess cancer risk of $10^{-5}$ and for noncarcinogenic contaminants a target HI of one (1.0) for residential and industrial land use. The target residential and industrial soil screening levels for selected substances are listed in the Department's Technical Background Document for Development of Soil Screening Levels (as updated).

- LANL shall comply with the surface water quality standards outlined in the Clean Water Act (33 U.S.C. $\S \S 1251$ to 1387), the New Mexico WQCC Regulations (20.6.2 NMAC), the State of New Mexico Standards for Interstate and Intrastate Surface Waters (20.6.4 NMAC) and the procedures for alternative abatement standards (20.6.2.4103 NMAC).

LANL may seek a variance from a remedial cleanup goal or level identified above, by submitting a demonstration to the Department that achievement of the cleanup goal or level is impracticable.

\section{AEC Immediate Action Directive 0511-21}

Scope: 
Requirement for retrievable storage of Transuranic (TRU) waste burial after April 30, 1970.

\section{Applicability:}

TRU waste shall be segregated from other waste and buried in a manner that is readily retrievable as contamination-free packages. Offices that can not comply shall request an exception, in writing, which states the reason for non-compliance and indicates the date when compliance can be achieved.

\section{Performance Requirements:}

Not applicable

\section{DOE Order 458.1, Radiation Protection of the Public and the Environment} (previous related order: DOE Order 5400.5, Radiation Protection of the Public and the Environment)

\section{$\underline{\text { Scope: }}$}

Requirements for the protection of the public and the environment against undue risk from radiation associated with radiological activities conducted under the control of the Department of Energy (DOE).

\section{Applicability:}

3) a. (1) This Order applies to all Departmental elements that are responsible for, or provide support for, the management and operation of DOE sites conducting radiological activities or management of DOE radioactive material or property that can result in exposures of the public to radiation or radioactive material.

4) h. (1) (b) DOE management of spent nuclear fuel, and high-level and transuranic wastes at a disposal facility which is not regulated by the NRC must comply with the requirements of this Order and 40 CFR Part 191, Environmental Radiation Protection Standards for Management and Disposal of Spent Nuclear Fuel, High-level and Transuranic Radioactive Wastes.

\section{Performance Requirements:}

4) b. Public Dose Limit.

(1) DOE radiological activities, including remedial actions and activities using Technologically Enhanced Naturally Occurring Radioactive Material (TENORM), must be conducted so that exposure of members of the public to ionizing radiation will: 
(a) Not cause a total effective dose (TED) exceeding $100 \mathrm{mrem}(1 \mathrm{mSv})$ in a year, an equivalent dose to the lens of the eye exceeding $1500 \mathrm{mrem}(15 \mathrm{mSv})$ in a year, or an equivalent dose to the skin or extremities exceeding $5000 \mathrm{mrem}(50 \mathrm{mSv})$ in a year, from all sources of ionizing radiation and exposure pathways that could contribute significantly to the total dose excepting:

1 Dose from radon and its decay products in air [Radon is regulated separately e.g., under Paragraphs 4.f. and 4.h.(1)(d) in this Order and under Title 40 Code of Federal Regulations (CFR) Part 61, Subparts Q and T];

2 Dose received by patients from medical sources of radiation, and by volunteers in medical research programs;

3 Dose from background radiation;

4 Dose from occupational exposure under NRC or Agreement State license or to general employees regulated under 10 CFR Part 835, and

(b) Comply with ALARA requirements in paragraph 4.d. of this Order.

(2) The public dose limit applies to members of the public located off DOE sites and on DOE sites outside of controlled areas, and to those exposed to residual radioactive material subsequent to any remedial action or clearance of property.

4) e. Demonstrating Compliance with the Public Dose Limit.

(1) Dose evaluations to demonstrate compliance with the public dose limit in paragraph 4.b.

(1) of this Order and to assess collective dose must include the following:

(c) The dose to members of the public from DOE-related exposure sources only, if the projected DOE-related dose to the representative person or MEI is $25 \mathrm{mrem}$ $(0.25 \mathrm{mSv})$ in a year or less. If the DOE-related dose is greater than $25 \mathrm{mrem}$ in a year, the dose to members of the public must include both major non-DOE sources of exposure (excluding dose from radon and its decay products in air, background radiation dose, occupational doses and doses due to medical exposures) and dose from DOE-related sources.

4) f. Airborne Radioactive Effluents. Radiological activities must be conducted in a manner such that the release of radioactive material to the atmosphere will:

(2) Not cause radon-222 flux rates to exceed $20 \mathrm{pCi}(0.7 \mathrm{~Bq}) \mathrm{m}-2$ sec-1 averaged over the surface area overlaying waste, including the covering or other confinement structures, wherever radium-226 wastes are accepted for storage or disposal (See 40 CFR Part 61, Subparts Q and T);

(5)Not exceed $3 \mathrm{pCi} / \mathrm{L}$ annual average radon-220 and radon-222 concentration, not including background, at the site boundary if DOE activities release radon-220 and radon-222 or their decay products.

4) h. Radioactive Waste and Spent Nuclear Fuel.

(1) Management, Storage and Disposal of Radioactive Waste.

(b) DOE management of spent nuclear fuel, and high-level and transuranic wastes at a disposal facility which is not regulated by the NRC must comply with the requirements of this Order and 40 CFR Part 191, Environmental Radiation Protection Standards for Management and Disposal of Spent Nuclear Fuel, Highlevel and Transuranic Radioactive Wastes. 
4) i. Protection of Drinking Water and Ground Water.

(2) Ground water must be protected from radiological contamination to ensure compliance with dose limits in the Order and consistent with ALARA process requirements. To this end, DOE must ensure that:

(a) Baseline conditions of the ground water quantity and quality are documented;

(b) Possible sources of, and potential for, radiological contamination are identified and assessed;

(c) Strategies to control radiological contamination are documented and implemented;

(d) Monitoring methodologies are documented and implemented; and

(e) Ground water monitoring activities are integrated with other environmental monitoring activities.

\section{DOE Order 435.1, Radioactive Waste Management}

(previous related order: DOE Order 5820.2A, Radioactive Waste Management)

\section{Scope:}

Requirements for management (i.e. storage, treatment, and disposal) of DOE high-level waste, transuranic waste, low-level waste, and the radioactive component of mixed waste

Applicability:

CHAPTER III Transuranic Waste Requirements

A. Definition of Transuranic Waste. Transuranic waste is radioactive waste containing more than 100 nanocuries ( 3700 becquerels) of alpha-emitting transuranic isotopes per gram of waste, with half-lives greater than 20 years, except for:

(1) High-level radioactive waste;

(2) Waste that the Secretary of Energy has determined, with the concurrence of the Administrator of the Environmental Protection Agency, does not need the degree of isolation required by the 40 CFR Part 191 disposal regulations; or

(3) Waste that the Nuclear Regulatory Commission has approved for disposal on a caseby-case basis in accordance with 10 CFR Part 61. (This is taken to mean that TRU waste may be disposed within an NRC licensed low-level waste disposal facility if approved by NRC on a case-by-case basis)

B. Management of Specific Wastes. The following provide for management of specific wastes as transuranic waste in accordance with the requirements in this Chapter:

(1) Mixed Transuranic Waste. Transuranic waste determined to contain both a hazardous component subject to the Resource Conservation and Recovery Act (RCRA), as amended, and a radioactive component subject to the Atomic Energy Act of 1954, as 
amended, shall be managed in accordance with the requirements of RCRA and DOE O 435.1, Radioactive Waste Management, and this Manual.

(3) Pre-1970 Transuranic Waste. Transuranic waste disposed of prior to implementation of the 1970 Atomic Energy Commission Immediate Action Directive regarding retrievable storage of transuranic waste is not subject to the requirements of DOE O 435.1, Radioactive Waste Management, and this Manual.

P. Disposal. Transuranic waste shall be disposed in accordance with the requirements of 40 CFR Part 191, Environmental Radiation Protection Standards for Management and Disposal of Spent Nuclear Fuel, High-Level and Transuranic Radioactive Wastes.

\section{Performance Requirements:}

See 40 CFR Part 191, Environmental Radiation Protection Standards for Management and Disposal of Spent Nuclear Fuel, High-Level and Transuranic Radioactive Wastes.

\section{CFR Part 191, Environmental Radiation Protection Standards for Management and Disposal of Spent Nuclear Fuel, High-Level and Transuranic Radioactive Wastes (EPA)}

Scope:

Requirements for management (i.e. storage and disposal) of Spent Nuclear Fuel, High-Level and Transuranic Radioactive Wastes after November 18, 1985.

Applicability:

Subpart A - Environmental Standards for Management and Storage

191.02 Definitions.

(i) Transuranic radioactive waste, as used in this part, means waste containing more than 100 nanocuries of alpha-emitting transuranic isotopes, with half-lives greater than twenty years, per gram of waste, except for: (1) High-level radioactive wastes; (2) wastes that the Department has determined, with the concurrence of the Administrator, do not need the degree of isolation required by this part; or (3) wastes that the Commission has approved for disposal on a case-by-case basis in accordance with 10 CFR Part 61.

Subpart B - Environmental Standards for Disposal

191.11 Applicability.

(a) This subpart applies to:

(1) Radioactive materials released into the accessible environment as a result of the disposal of spent nuclear fuel or high-level or transuranic radioactive wastes;

(2) Radiation doses received by members of the public as a result of such disposal; and 
(3) Radioactive contamination of certain sources of ground water in the vicinity of disposal systems for such fuel or wastes.

(b) This subpart does not apply to:

(1) Disposal directly into the oceans or ocean sediments;

(2) Wastes disposed of before November 18, 1985; and

(3) The characterization, licensing, construction, operation, or closure of any site required to be characterized under Section 113(a) of Public Law 97-425, 96 Stat. 2201.

191.12 Definitions.

Implementing agency means:

(1) The Commission for facilities licensed by the Commission;

(2) The Agency for those implementation responsibilities for the Waste Isolation Pilot Plant, under this part, given to the Agency by the Waste Isolation Pilot Plant Land Withdrawal Act (Pub. L. 102-579, 106 Stat. 4777) which, for the purposes of this part, are:

(vi)Concurrence by the Agency with the Department's determination under $\S 191.02$ (i) that certain wastes do not need the degree of isolation required by subparts $\mathrm{B}$ and $\mathrm{C}$ of this part; and

(3) The Department of Energy for any other disposal facility and all other implementation responsibilities for the Waste Isolation Pilot Plant, under this part, not given to the Agency.

191.16 Alternative provisions for disposal.

The Administrator may, by rule, substitute for any of the provisions of subpart B alternative provisions chosen after:

(a) The alternative provisions have been proposed for public comment in the Federal Register together with information describing the costs, risks, and benefits of disposal in accordance with the alternative provisions and the reasons why compliance with the existing provisions of Subpart B appears inappropriate;

(b) A public comment period of at least 90 days has been completed, during which an opportunity for public hearings in affected areas of the country has been provided; and

(c) The public comments received have been fully considered in developing the final version of such alternative provisions.

191.17 Effective date.

The standards in this subpart shall be effective on November 18, 1985.

Performance Requirements:

191.13 Containment requirements:

(a) Disposal systems for spent nuclear fuel or high-level or transuranic radioactive wastes shall be designed to provide a reasonable expectation, based upon performance assessments, that the cumulative releases of radionuclides to the accessible 
environment for 10,000 years after disposal from all significant processes and events that may affect the disposal system shall:

(1) Have a likelihood of less than one chance in 10 of exceeding the quantities calculated according to Table 1 (appendix A); and

(2) Have a likelihood of less than one chance in 1,000 of exceeding ten times the quantities calculated according to Table 1 (appendix A).

(b) Performance assessments need not provide complete assurance that the requirements of $\S 191.13$ (a) will be met. Because of the long time period involved and the nature of the events and processes of interest, there will inevitably be substantial uncertainties in projecting disposal system performance. Proof of the future performance of a disposal system is not to be had in the ordinary sense of the word in situations that deal with much shorter time frames. Instead, what is required is a reasonable expectation, on the basis of the record before the implementing agency, that compliance with $\S 191.13$ (a) will be achieved.

191.15 Individual protection requirements

(a) Disposal systems for waste and any associated radioactive material shall be designed to provide a reasonable expectation that, for 10,000 years after disposal, undisturbed performance of the disposal system shall not cause the annual committed effective dose, received through all potential pathways from the disposal system, to any member of the public in the accessible environment, to exceed 15 millirems (150 microsieverts).

(b) Annual committed effective doses shall be calculated in accordance with appendix B of this part.

(c) Compliance assessments need not provide complete assurance that the requirements of paragraph (a) of this section will be met. Because of the long time period involved and the nature of the processes and events of interest, there will inevitably be substantial uncertainties in projecting disposal system performance. Proof of the future performance of a disposal system is not to be had in the ordinary sense of the word in situations that deal with much shorter time frames. Instead, what is required is a reasonable expectation, on the basis of the record before the implementing agency, that compliance with paragraph (a) of this section will be achieved.

(e) The standards in this section shall be effective on January 19, 1994.

\section{CFR Part 300, National Oil And Hazardous Substances Pollution Contingency Plan (CERCLA)}

\section{$\underline{\text { Scope: }}$}

LANL is not listed on the Comprehensive Environmental Response, Compensation, and Liability Act (CERCLA) National Priorities List (NPL); therefore MDA-T is not currently subject to CERCLA. CERCLA provides two types of hazardous action responses: removal actions and remedial actions. Removal actions are shorter termed actions responding to a threat that can be the final action or followed by or be a part of a remedial action. Remedial actions are longer termed actions that are undertaken following the full CERCLA process: 
remedial investigation / feasibility study, proposed plan, record of decision, and remedial design / remedial action. Under CERCLA Section 104, 42 U.S.C. $§ 9604$, DOE can conduct CERCLA non-time critical removal actions under their own authority even at non-NPL sites. An extract from 40 CFR Part 300 concerning removal actions under DOE authority is provided below. Use of CERCLA remedial action authority at a non-NPL RCRA regulated site, such as LANL, would likely require integration of the full CERCLA process for radionuclides with the with the existing RCRA process for hazardous waste components. In the case of LANL this would likely require an agreement between DOE and NMED regarding such integration and would possibly require a modification of the NMED/LANL Consent Order. (EPA 1993, EPA/DOE/DOD 1994, and DOE/EPA 1995)

The Savannah River Site has such an agreement called the Federal Facility Agreement for the SRS between DOE, EPA, and the South Carolina Department of Health and Environmental Control (FFA 1993). The SRS FFA integrates DOE's SRS CERCLA response obligations with the corrective measures required by its current RCRA permit. The integration of response actions under CERCLA with the corrective measures under the SRS RCRA permit are intended to achieve comprehensive remediation of releases and threatened releases of hazardous substances, hazardous wastes, hazardous constituents, pollutants or contaminants at or from SRS. Thus, the response actions under CERCLA will address releases of radionuclides and other hazardous substances not presently addressed in the RCRA permit. Therefore, the Parties intend that activities covered by this Agreement will be deemed to achieve compliance with CERCLA, RCRA, and to meet or exceed all applicable or relevant and appropriate Federal and State laws and regulations, to the extent required by CERCLA.

\section{Applicability:}

40 CFR Part 300.5 Definitions.

Lead agency means the agency that provides the OSC/RPM to plan and implement response actions under the NCP.... In the case of a release of a hazardous substance, pollutant, or contaminant, where the release is on, or the sole source of the release is from, any facility or vessel under the jurisdiction, custody, or control of Department of Defense (DOD) or Department of Energy (DOE), then DOD or DOE will be the lead agency. ... The federal agency maintains its lead agency responsibilities whether the remedy is selected by the federal agency for non-NPL sites or by EPA and the federal agency or by EPA alone under CERCLA Section 120. The lead agency will consult with the support agency, if one exists, throughout the response process.

40 CFR Part 300.415 Removal action

(a)(1) In determining the appropriate extent of action to be taken in response to a given release, the lead agency shall first review the removal site evaluation, any information produced through a remedial site evaluation, if any has been done previously, and the current site conditions, to determine if removal action is appropriate.

(b)(1) At any release, regardless of whether the site is included on the National Priorities List (NPL), where the lead agency makes the determination, based on the factors 
in paragraph (b)(2) of this section, that there is a threat to public health or welfare of the United States or the environment, the lead agency may take any appropriate removal action to abate, prevent, minimize, stabilize, mitigate, or eliminate the release or the threat of release.

(2) The following factors shall be considered in determining the appropriateness of a removal action pursuant to this section:

(i) Actual or potential exposure to nearby human populations, animals, or the food chain from hazardous substances or pollutants or contaminants;

(ii) Actual or potential contamination of drinking water supplies or sensitive ecosystems;

(iii) Hazardous substances or pollutants or contaminants in drums, barrels, tanks, or other bulk storage containers, that may pose a threat of release;

(iv) High levels of hazardous substances or pollutants or contaminants in soils largely at or near the surface, that may migrate;

(v) Weather conditions that may cause hazardous substances or pollutants or contaminants to migrate or be released;

(vi) Threat of fire or explosion;

(vii) The availability of other appropriate federal or state response mechanisms to respond to the release; and

(viii) Other situations or factors that may pose threats to public health or welfare of the United States or the environment.

(3) If the lead agency determines that a removal action is appropriate, actions shall, as appropriate, begin as soon as possible to abate, prevent, minimize, stabilize, mitigate, or eliminate the threat to public health or welfare of the United States or the environment. The lead agency shall, at the earliest possible time, also make any necessary determinations pursuant to paragraph (b)(4) of this section.

(4) Whenever a planning period of at least six months exists before on-site activities must be initiated, and the lead agency determines, based on a site evaluation, that a removal action is appropriate:

(i) The lead agency shall conduct an engineering evaluation/cost analysis $(\mathrm{EE} / \mathrm{CA})$ or its equivalent. The EE/CA is an analysis of removal alternatives for a site.

(ii) If environmental samples are to be collected, the lead agency shall develop sampling and analysis plans that shall provide a process for obtaining data of sufficient quality and quantity to satisfy data needs. Sampling and analysis plans shall be reviewed and approved by EPA. The sampling and analysis plans shall consist of two parts:

(A) The field sampling plan, which describes the number, type, and location of samples and the type of analyses; and

(B) The quality assurance project plan, which describes policy, organization, and functional activities and the data quality objectives and measures necessary to achieve adequate data for use in planning and documenting the removal action. 
(d) Removal actions shall, to the extent practicable, contribute to the efficient performance of any anticipated long-term remedial action with respect to the release concerned.

(e) The following removal actions are, as a general rule, appropriate in the types of situations shown; however, this list is not exhaustive and is not intended to prevent the lead agency from taking any other actions deemed necessary under CERCLA, CWA Section 311, or other appropriate federal or state enforcement or response authorities, and the list does not create a duty on the lead agency to take action at any particular time:

(1) Fences, warning signs, or other security or site control precautions-where humans or animals have access to the release;

(2) Drainage controls, for example, run-off or run-on diversion-where needed to reduce migration of hazardous substances or pollutants or contaminants off-site or to prevent precipitation or run-off from other sources, for example, flooding, from entering the release area from other areas;

(3) Stabilization of berms, dikes, or impoundments or drainage or closing of lagoons - where needed to maintain the integrity of the structures;

(4) Capping of contaminated soils or sludges - where needed to reduce migration of hazardous substances or pollutants or contaminants into soil, ground or surface water, or air;

(5) Using chemicals and other materials to retard the spread of the release or to mitigate its effects - where the use of such chemicals will reduce the spread of the release;

(6) Excavation, consolidation, or removal of highly contaminated soils from drainage or other areas - where such actions will reduce the spread of, or direct contact with, the contamination;

(7) Removal of drums, barrels, tanks, or other bulk containers that contain or may contain hazardous substances or pollutants or contaminants - where it will reduce the likelihood of spillage; leakage; exposure to humans, animals, or food chain; or fire or explosion;

(8) Containment, treatment, disposal, or incineration of hazardous materials - where needed to reduce the likelihood of human, animal, or food chain exposure; or

(9) Provision of alternative water supply - where necessary immediately to reduce exposure to contaminated household water and continuing until such time as local authorities can satisfy the need for a permanent remedy.

(1) To the extent practicable, provision for post-removal site control following a CERCLA Fund-financed removal action at both NPL and non-NPL sites is encouraged to be made prior to the initiation of the removal action. Such postremoval site control includes actions necessary to ensure the effectiveness and integrity of the removal action after the completion of the on-site removal action or after the \$2 million or 12-month statutory limits are reached for sites that do not meet the exemption criteria in paragraph (b)(5) of this section. Post-removal site control may be conducted by:

(1) The affected state or political subdivision thereof or local units of government for any removal; 
(2) Potentially responsible parties; or

(3) EPA's remedial program for some federal-lead Fund-financed responses at NPL sites.

(n) Community relations in removal actions.

(1) In the case of all CERCLA removal actions taken pursuant to $\S 300.415$ or CERCLA enforcement actions to compel removal response, a spokesperson shall be designated by the lead agency. The spokesperson shall inform the community of actions taken, respond to inquiries, and provide information concerning the release. All news releases or statements made by participating agencies shall be coordinated with the OSC/RPM. The spokesperson shall notify, at a minimum, immediately affected citizens, state and local officials, and, when appropriate, civil defense or emergency management agencies.

(3) For CERCLA removal actions where on-site action is expected to extend beyond 120 days from the initiation of on-site removal activities, the lead agency shall by the end of the 120-day period:

(i) Conduct interviews with local officials, community residents, public interest groups, or other interested or affected parties, as appropriate, to solicit their concerns, information needs, and how or when citizens would like to be involved in the Superfund process;

(ii) Prepare a formal community relations plan (CRP) based on the community interviews and other relevant information, specifying the community relations activities that the lead agency expects to undertake during the response; and

(iii) Establish at least one local information repository at or near the location of the response action. The information repository should contain items made available for public information. Further, an administrative record file established pursuant to subpart I for all removal actions shall be available for public inspection in at least one of the repositories. The lead agency shall inform the public of the establishment of the information repository and provide notice of availability of the administrative record file for public review. All items in the repository shall be available for public inspection and copying.

(4) Where, based on the site evaluation, the lead agency determines that a CERCLA removal action is appropriate and that a planning period of at least six months exists prior to initiation of the on-site removal activities, the lead agency shall at a minimum:

(i) Comply with the requirements set forth in paragraphs (n)(3)(i), (ii), and (iii) of this section, prior to the completion of the EE/CA, or its equivalent, except that the information repository and the administrative record file will be established no later than when the EE/CA approval memorandum is signed;

(ii) Publish a notice of availability and brief description of the EE/CA in a major local newspaper of general circulation pursuant to $\S 300.820$; 
(iii) Provide a reasonable opportunity, not less than 30 calendar days, for submission of written and oral comments after completion of the EE/CA pursuant to $\$ 300.820$ (a). Upon timely request, the lead agency will extend the public comment period by a minimum of 15 days; and

(iv) Prepare a written response to significant comments pursuant to $\S 300.820(a)$.

\section{Performance Requirements:}

Typical performance requirements under CERCLA include:

- $10^{-4}$ to $10^{-6}$ lifetime excess cancer risk

- Hazard Index (HI) of one

\section{CFR Part 61, Licensing Requirements for Land Disposal of Radioactive Waste (NRC)}

Scope:

Requirements for land disposal of radioactive waste under a Nuclear Regulatory Commission (NRC) license.

Applicability:

61.1 Purpose and scope.

(a) The regulations in this part establish, for land disposal of radioactive waste, the procedures, criteria, and terms and conditions upon which the Commission issues licenses for the disposal of radioactive wastes containing byproduct, source and special nuclear material received from other persons. Disposal of waste by an individual licensee is set forth in part 20 of this chapter. Applicability of the requirements in this part to Commission licenses for waste disposal facilities in effect on the effective date of this rule will be determined on a case-by-case basis and implemented through terms and conditions of the license or by orders issued by the Commission. (effective date of December 27, 1982, unless otherwise noted)

(10 CFR Part 61 is potentially applicable to MDA-T in the sense that MDA-T TRU waste could be excavated and disposed within an NRC licensed low-level waste disposal facility, if approved by NRC on a case-by-case basis)

\section{Performance Requirements:}

Subpart C-Performance Objectives

61.40 General requirement. Land disposal facilities must be sited, designed, operated, closed, and controlled after closure so that reasonable assurance exists that exposures to humans are within the limits established in the performance objectives in 61.41 through 61.44 .

61.41 Protection of the general population from releases of radioactivity. 
Concentrations of radioactive material which may be released to the general environment in ground water, surface water, air, soil, plants, or animals must not result in an annual dose exceeding an equivalent of 25 millirems to the whole body, 75 millirems to the thyroid, and 25 millirems to any other organ of any member of the public. Reasonable effort should be made to maintain releases of radioactivity in effluents to the general environment as low as is reasonably achievable.

61.42 Protection of individuals from inadvertent intrusion. Design, operation, and closure of the land disposal facility must ensure protection of any individual inadvertently intruding into the disposal site and occupying the site or contacting the waste at any time after active institutional controls over the disposal site are removed.

61.58 Alternative requirements for waste classification and characteristics.

The Commission may, upon request or on its own initiative, authorize other provisions for the classification and characteristics of waste on a specific basis, if, after evaluation, of the specific characteristics of the waste, disposal site, and method of disposal, it finds reasonable assurance of compliance with the performance objectives in subpart $\mathrm{C}$ of this part.

\section{DOE Order 5820.2A, Radioactive Waste Management - Cancelled}

(superseded by: DOE Order 435.1, Radioactive Waste Management)

\section{$\underline{\text { Scope: }}$}

Included a section that specifically addressed buried tansuranic contaminated waste at DOE inactive waste sites including LANL. This section was not placed in the currently active DOE Order 435.1.

\section{Applicability:}

Chapter II, Management of Transuranic Waste, 3. Requirements, i. Buried TransuranicContaminated Waste.

(1) Alternatives for the long term management of buried transuranic contaminated waste at inactive DOE waste sites are addressed in Attachment 1, page 3, paragraph 22 (i.e. DOEJIO-025 of 9-87, "Comprehensive Implementation Plan for the DOE Defense Buried Transuranic-Contaminated Waste Program”). The inactive waste sites are located at Idaho National Engineering Laboratory, Los Alamos National Laboratory, Oak Ridge National Laboratory, Savannah River Plant, and the Hanford Site. The program will lead to the closure of each waste site, in compliance with the National Environmental Policy Act requirements, the Comprehensive Environmental Response, Compensation, and Liability Act, the Superfund Amendments and Reauthorization Act, and other applicable DOE, EPA, and State requirements.

(2) Each waste site shall be characterized to include information on types and quantities of radioactive and hazardous chemicals. This information shall be verified by appropriate sampling/analysis/monitoring techniques. The characterization and verification activities will also include determination of waste migration from the burial sites and potential environmental and health impacts. 
(3) Each DOE site will develop a closure strategy for the waste site(s), utilizing the waste characterization data. Basic site-closure strategies which could be a combination of (a), (b), and (c) depending on site-specific and regulatory requirements, are as follows:

(a) Leave waste in place with enhanced monitoring.

(b) Leave waste in place, use enhanced confinement or in situ immobilization techniques, and provide enhanced monitoring.

(c) Retrieve, process, and dispose of the transuranic waste at Waste Isolation Pilot Plant.

(4) Each DOE site will develop a site closure plan, which will include, as a minimum, the following:

(a) National Environmental Policy Act requirements;

(b) Applicable Federal, State and local regulations (e.g., DOE, EPA, State);

(c) Permits required;

(d) Selected closure strategy and justification;

(e) A waste retrieval strategy:

1 Methodology for segregating transuranic and low-level waste,

2 Identification of mixed waste components,

3 Certification of transuranic waste for disposal at the Waste Isolation Pilot Plant,

4 Management of low-level waste and mixed waste, and

5 Plans for maintaining exposures as low as reasonably achievable;

(f) Budget requirements by fiscal year;

(g) Schedule for closure strategy completion; and

(h) Post-closure monitoring and controls.

Performance Requirements:

Not applicable

The following are other active DOE Policies, Orders, and Guides that could have some pertinence to MDA-T decision making:

- DOE G 413.3-8 Environmental Management (EM) Cleanup Projects

- DOE O 450.1A Environmental Protection Program

- DOE P 450.2A Identifying, Implementing and Complying with Environment, Safety and Health Requirements

- DOE P 455.1 Use of Risk-Based End States

The following are cancelled DOE Orders that could have some historical significance to MDA-T decision making:

- DOE Order 5480.2, Hazardous and Radioactive Mixed Waste Management

- DOE Order 5400.3 Hazardous And Radioactive Mixed Waste Program

- DOE Order 5400.5, Radiation Protection of the Public and the Environment

- DOE 5820.2, Radioactive Waste Management (not included in the current DOE Order archive but cancelled by DOE O 5820.2A) 
- DOE Order 5820.2A, Radioactive Waste Management (a review of this cancelled order in relation to its requirements for buried tansuranic contaminated waste at DOE inactive waste sites including LANL is provided above)

- DOE Order 5820.1 Management of Transuranic Contaminated Material (not included in the current DOE Order archive but referenced within DOE O 5480.2)

The following is a DOE document, available for purchase through the National Technical Information Service (NTIS product code DE87012428) that could have some historical significance to MDA-T decision making, since it describes long term management alternatives for all DOE sites with buried transuranic waste including that at LANL:

DOE-JIO-025 of 9-87, “Comprehensive Implementation Plan for the DOE Defense Buried Transuranic-Contaminated Waste Program"

Review of the following regulations is not required in order to determine the regulatory pathforward for the radionuclide components of the legacy waste at the MDA-T. However these regulations would need to be considered in regards to the selected corrective action.

- 10 CFR Part 830, Nuclear Safety Management (DOE)

- 10 CFR Part 835 Occupational Radiation Protection (DOE) 
SRNL-STI-2010-00298

$6 / 27 / 11$ 
SRNL-STI-2010-00298

$6 / 27 / 11$ 